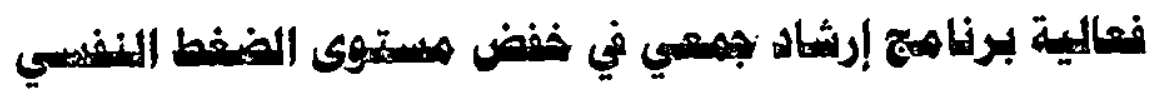

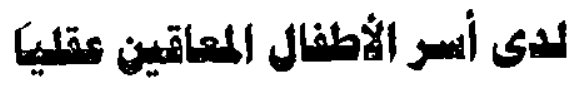

$$
\text { ! }
$$

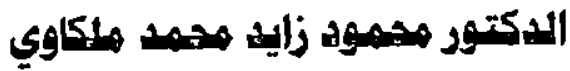

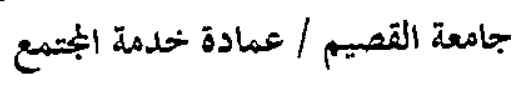

المملكة العربية السعودية

$$
\text { كلمام الدراسي }
$$


فعالية برنامج إرشاد جسعي في خفض مستوى الضنط النفسي لاى الس الأطفال المعاتين عظيا

\section{هذص الثدراسة}

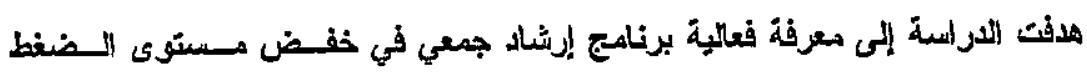

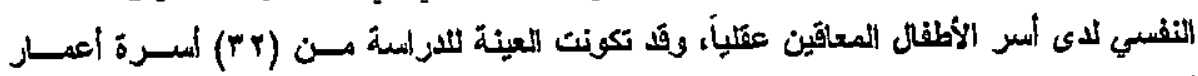

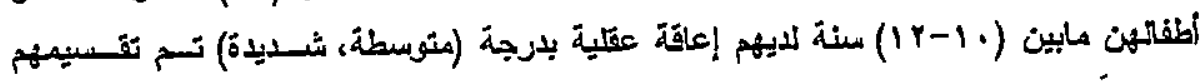

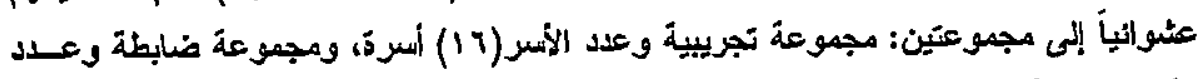

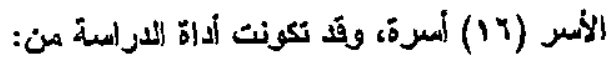

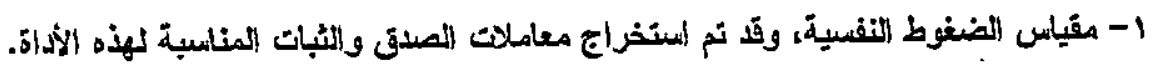

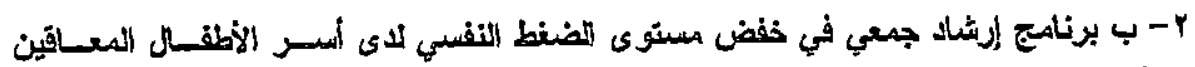

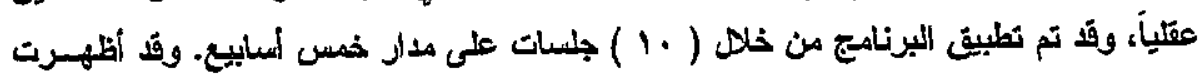

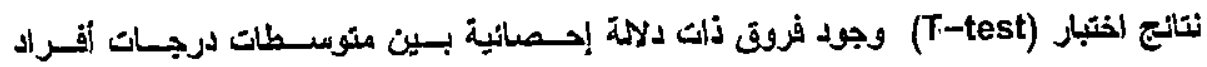

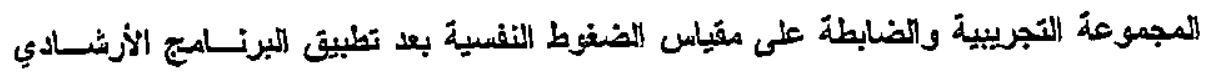

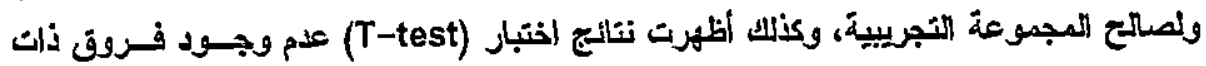

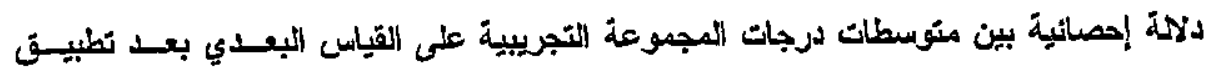

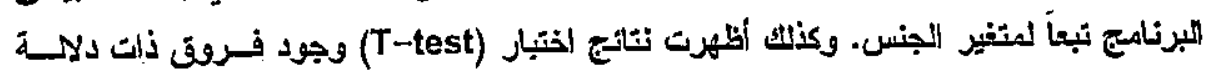

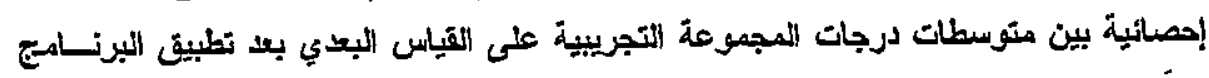
تبعاً أمتغير درجة الإعاقة. 
فعالية برنامج إرشاد جمعي في خفض مستوى الضغط التفسي للاى أسبر الأطفل المعاقين عثليا

\section{المدهمة}

تمثل الأسرة كياتاً بارزا في العجتمعات الإساتية، وبتشكل رعاية الطقل أولمية في حياة الأسرة.

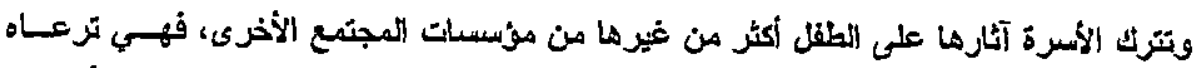

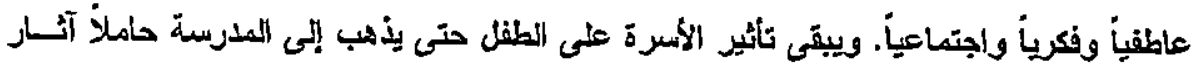

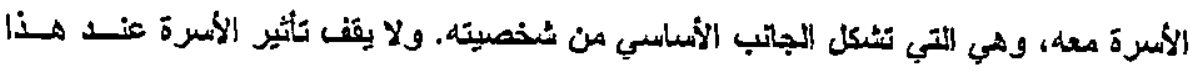

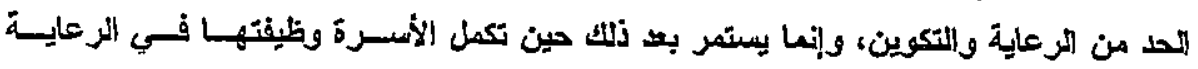

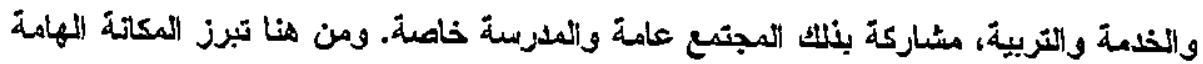

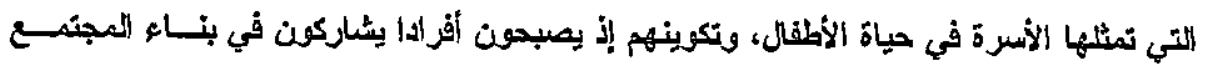

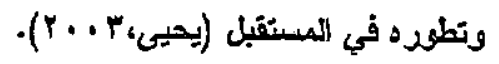

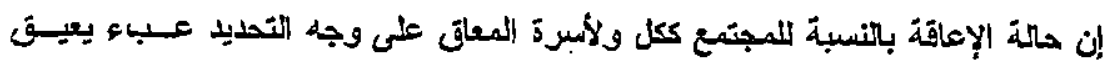

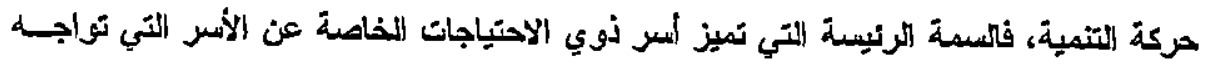

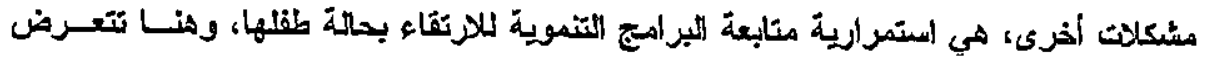

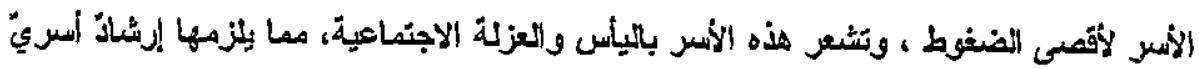

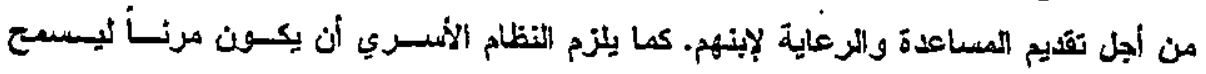

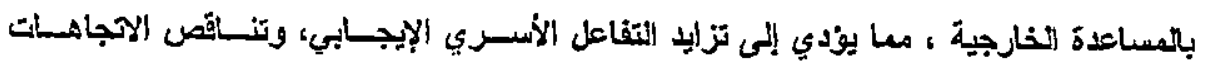

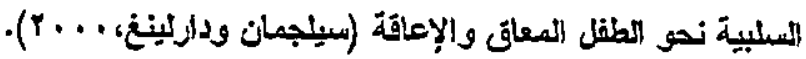

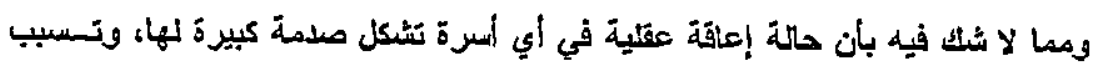

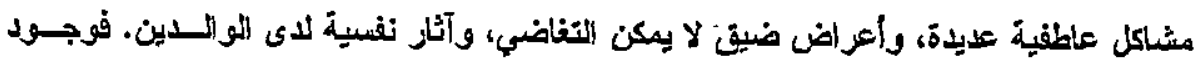

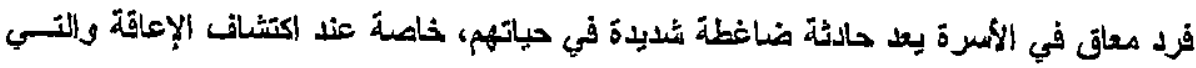

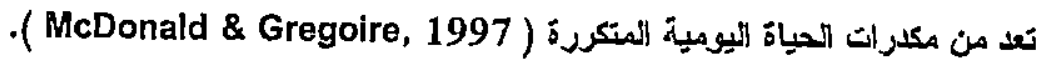

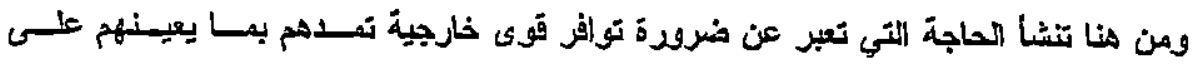

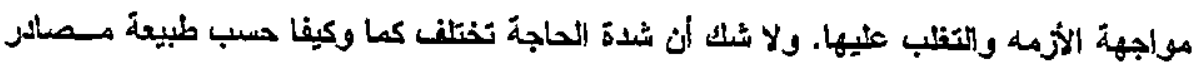

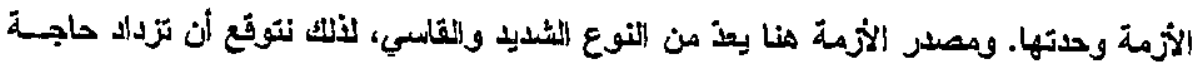

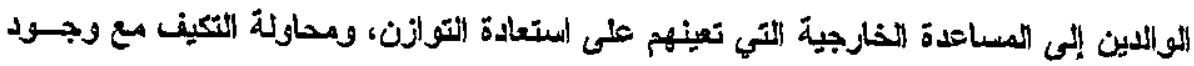

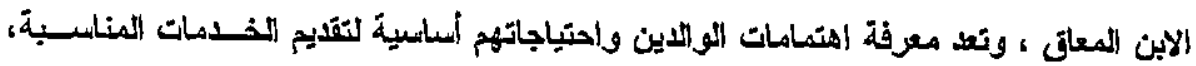
والدعم الفاعل الأي يعينهم على تحقيق التكيف المنشود. 


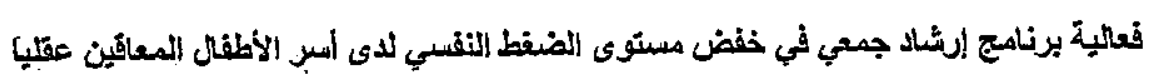

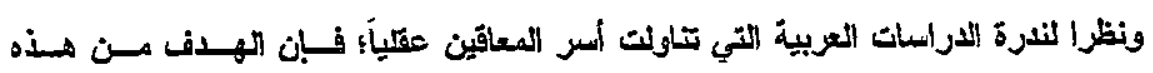

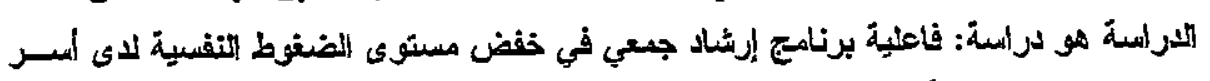
الأطفال المعالقين عقلياً. -

تسعى هذه الاراسة إلى الكثف عن فعالية برنامج إرشاد جمعي في خفض مستوى الضغط

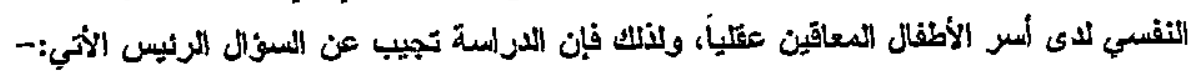

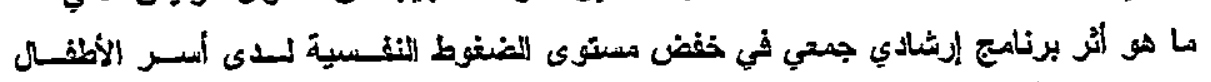

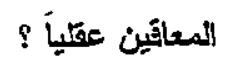

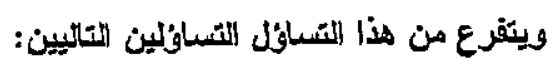

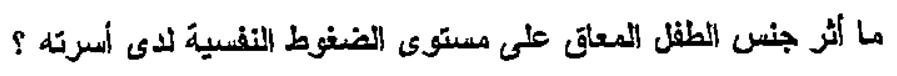

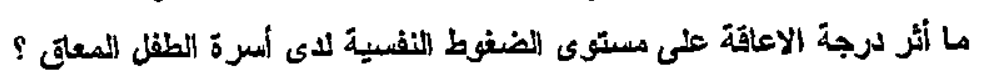

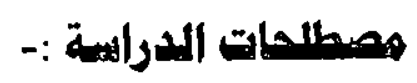

ئill

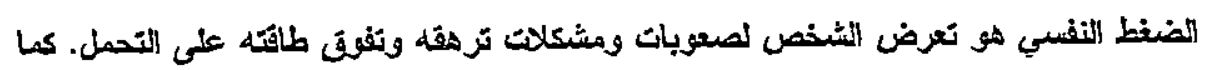

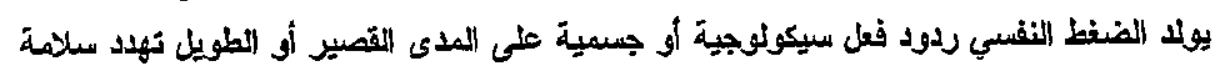

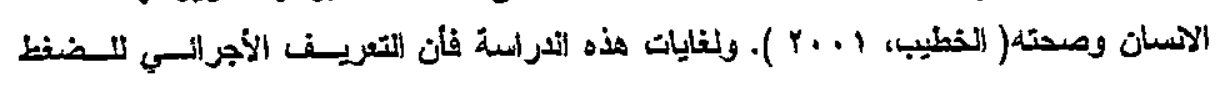

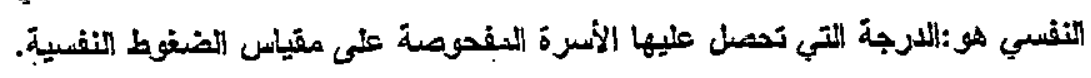

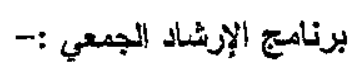

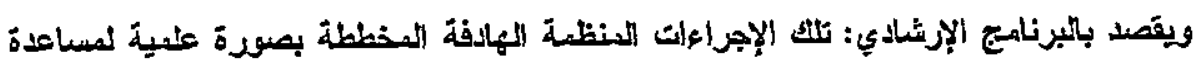

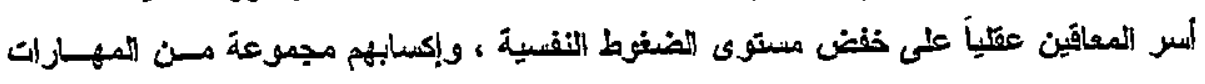

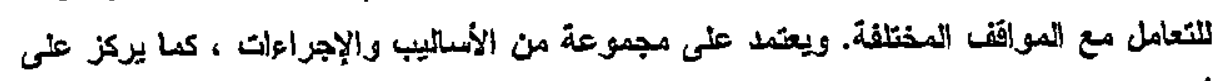

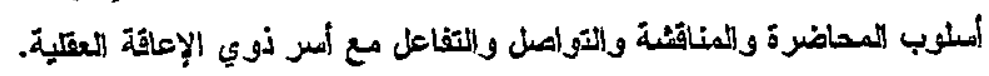
الاعاقة العملية:-

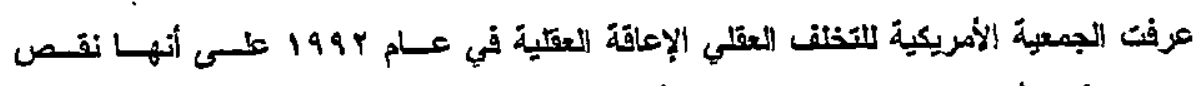

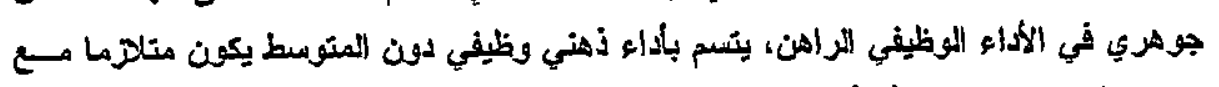

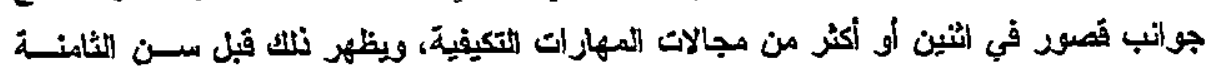

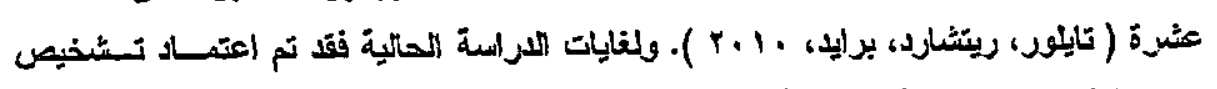
مركز التشخيص المبكر في المملكة الاردنية الهابثمية. 
فعلية برنامج إرشاد جمعي في خفض مستوى الضنط النفسي لدى أسر الأطفل المعاقين عقليا

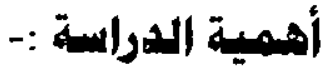

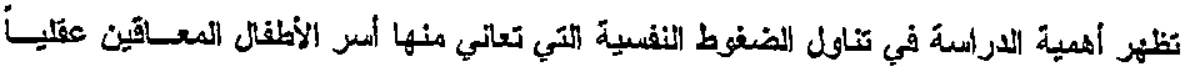

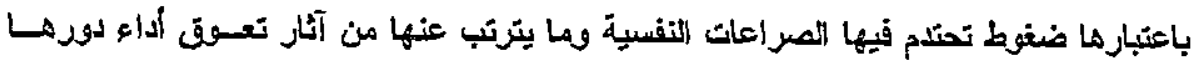

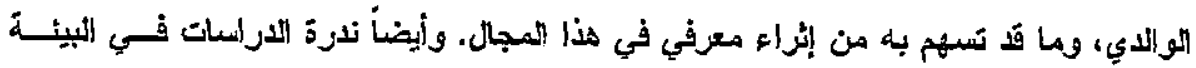

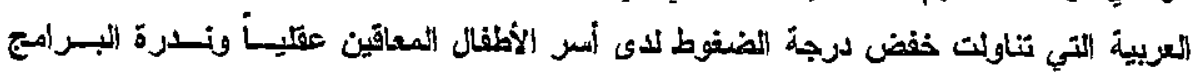

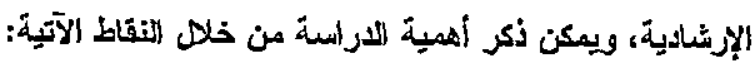

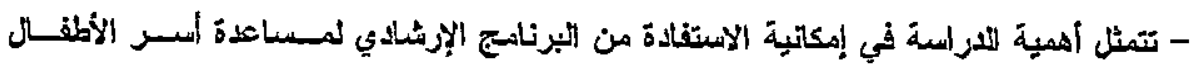
المعاقين عقلياً

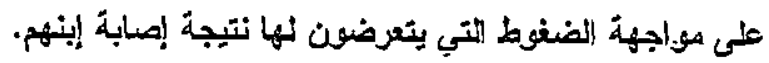

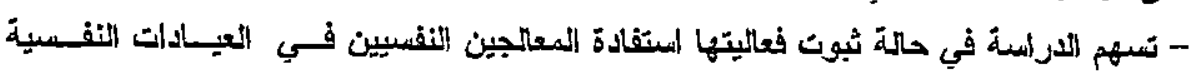

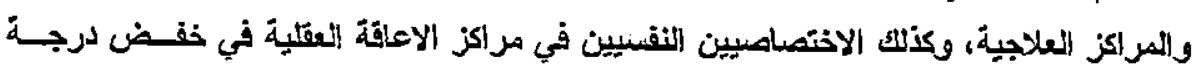
الفضوط النفسية دي أسر الأطفال المعاقين عقلياً.

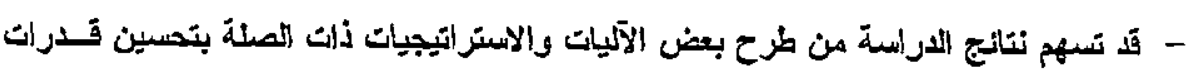

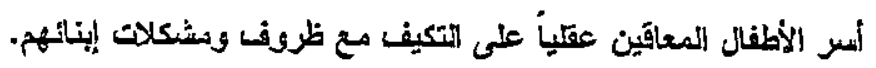

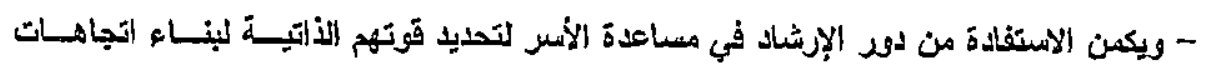
إيجابية نحو الإعاقة.

\section{حدوه الدوراسة:}

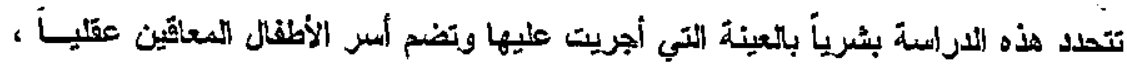

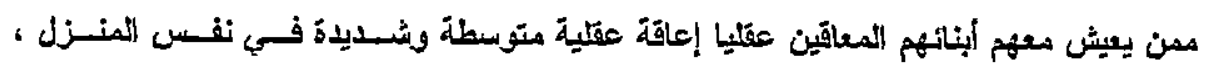

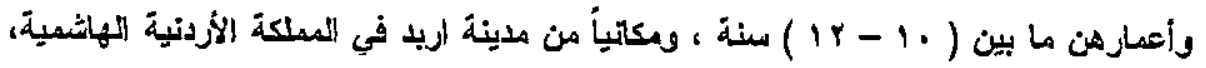

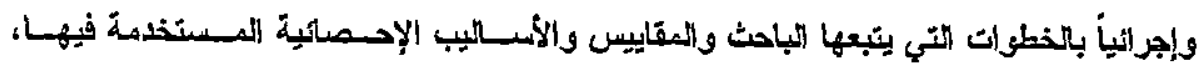

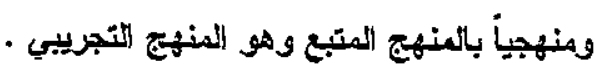

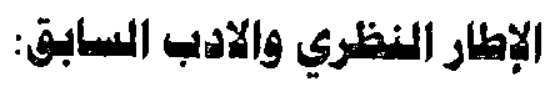

أوهاً : الإطار النفظري:

קטفة

تعد الأسرة نظامأ منكاملاً يضم مجموعة من الأعضاء يؤثر كل منهم في الآخر وينأثر بهم،

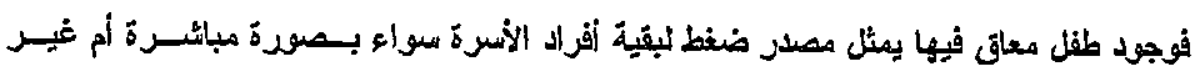


فعاتلية برنامج إرشاد جمعي في خفض مستوى الضنط النفسي ثلى أسر الأطفلل المعاقين عثليا

مباشرة ، مما يترتب عليه تلبية بعض الاحتياجات التئ تصكن الأسرة مسـن مواجهــة الــضضوط النفسية الناجمة عن إعاقة الطقل.

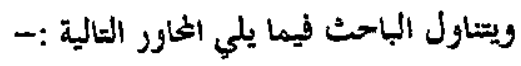

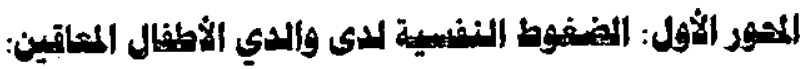

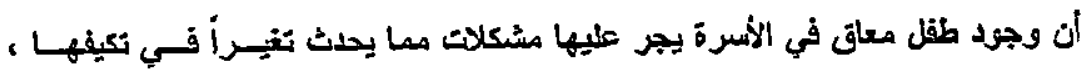

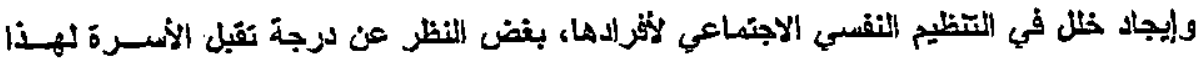

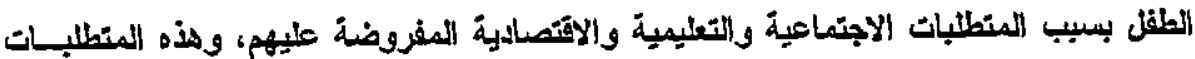

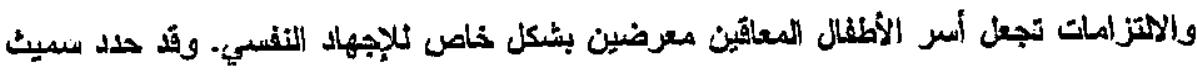

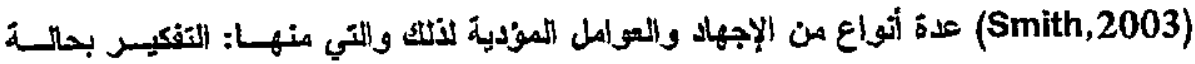

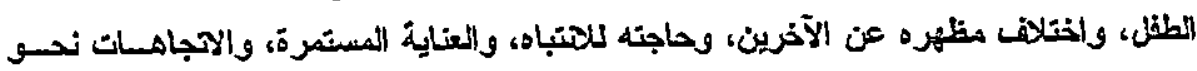

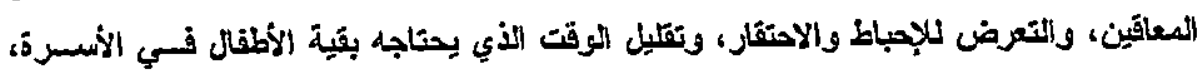

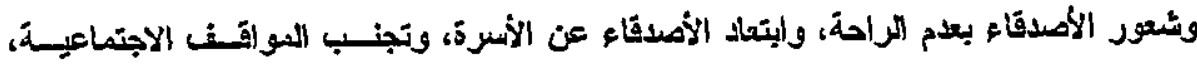

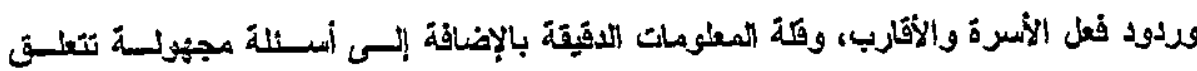

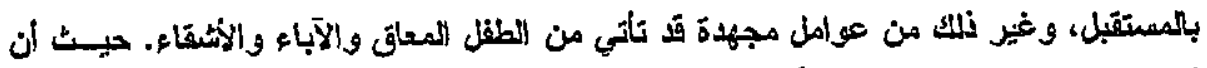

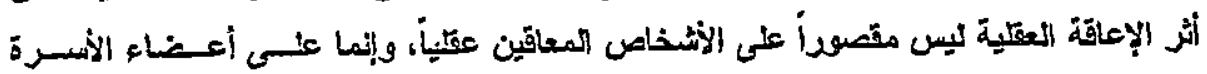
التريبة والممتلة بدرجات متفاونة.

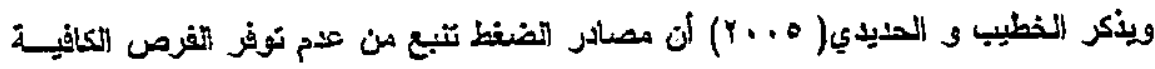

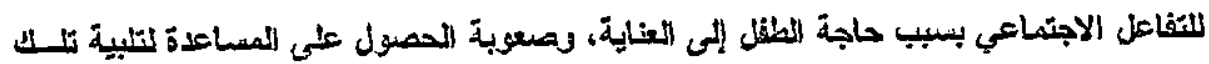

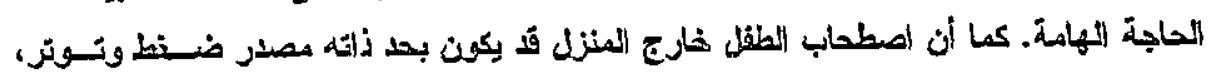

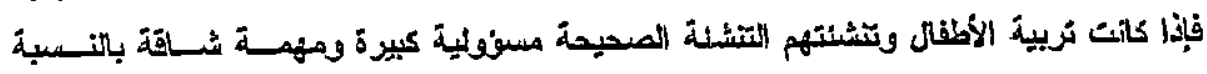

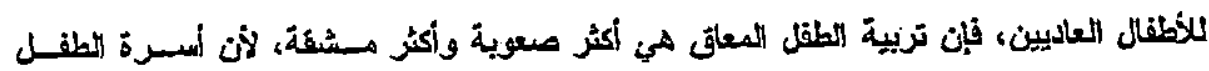

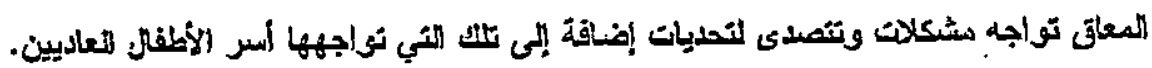

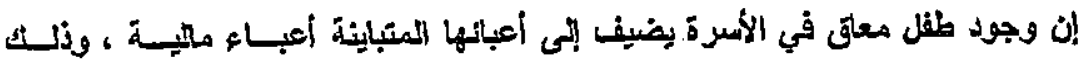

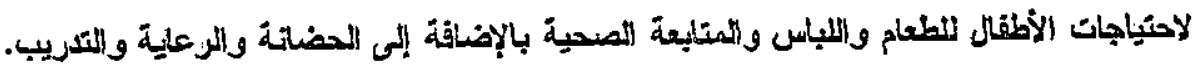

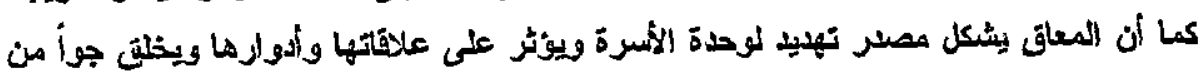

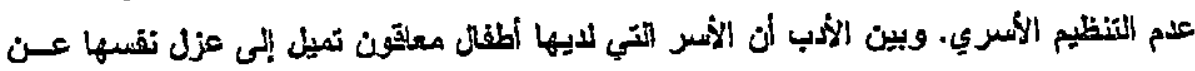

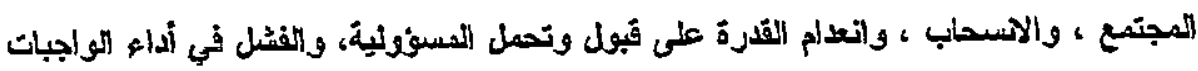

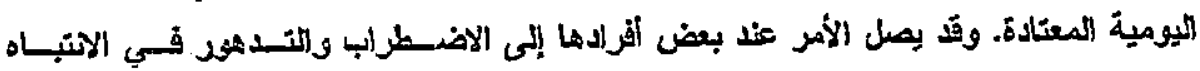


فعلية برنامج إرثشاد جمعي في خفض مستوى الضفط النفسيى لاى أسر الأطفل المعاقّين عقليا

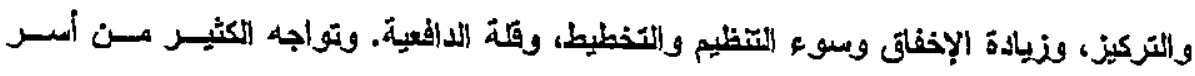

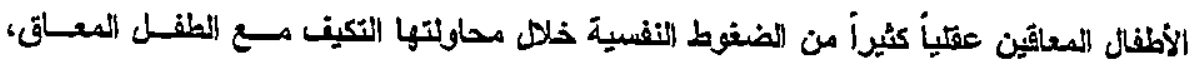

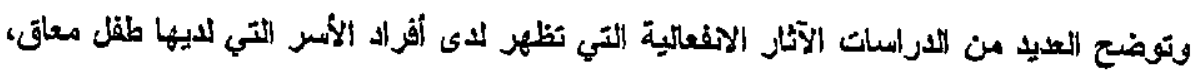

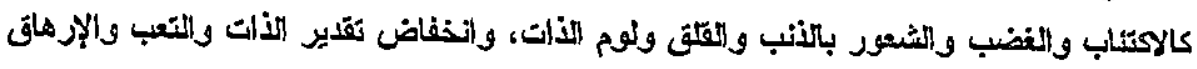

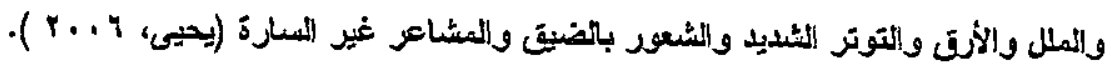

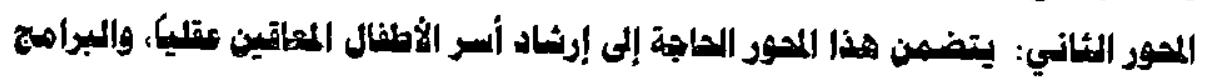

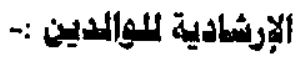

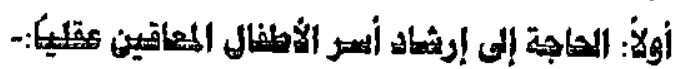

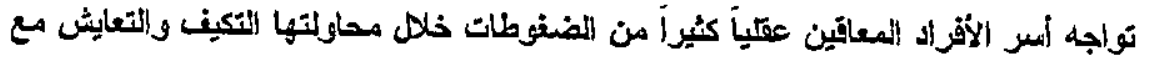

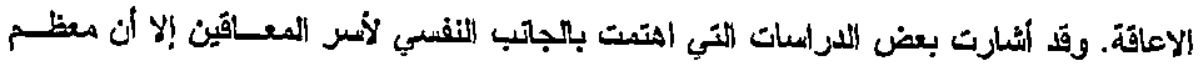

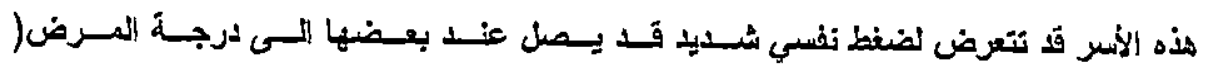

. (Carpenter,2000

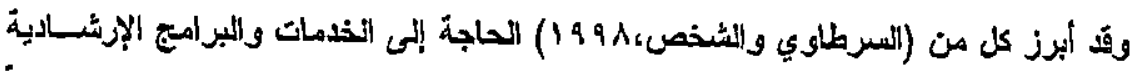

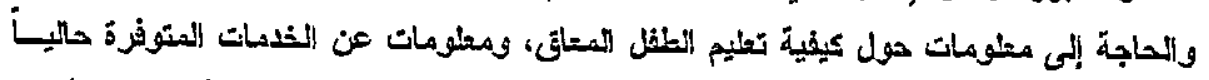

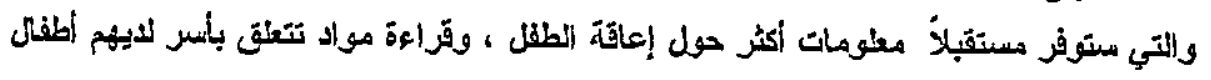
معافقون.

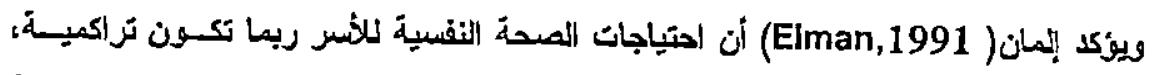

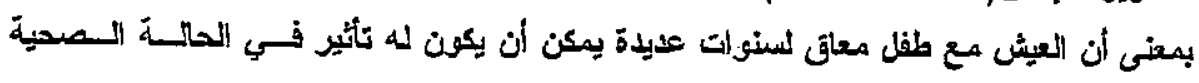

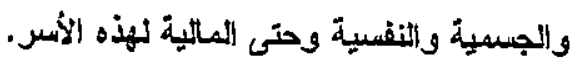

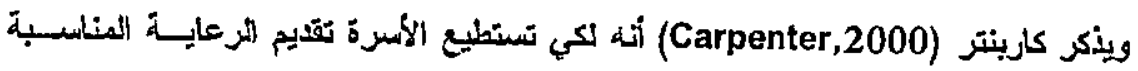

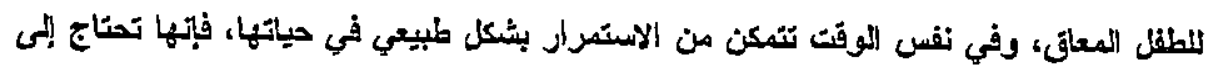

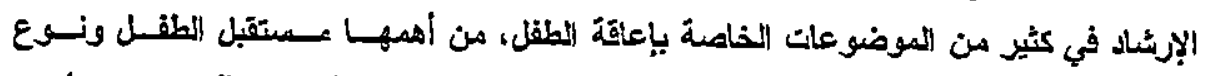

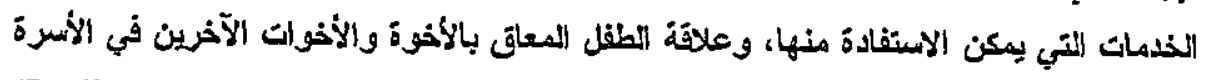

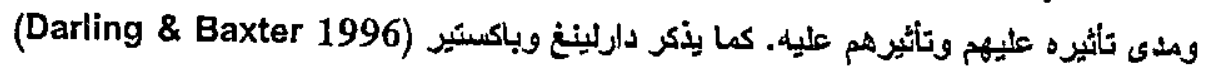

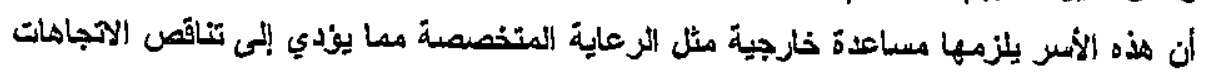

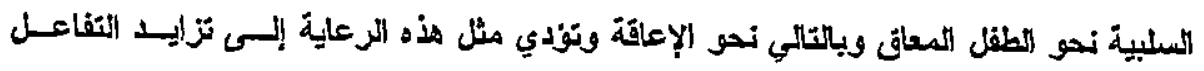

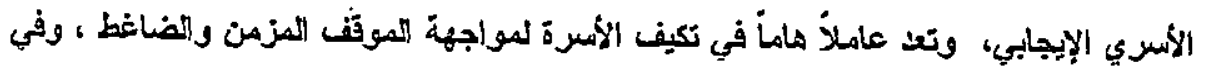

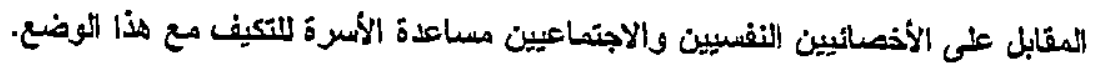




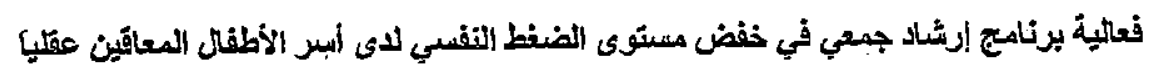

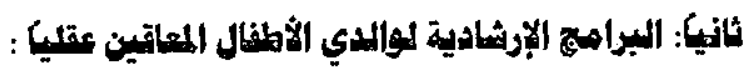

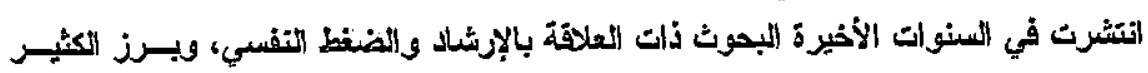

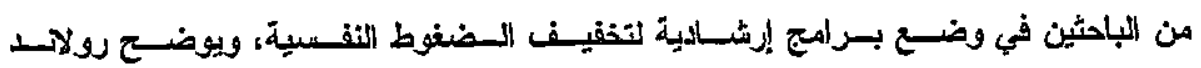

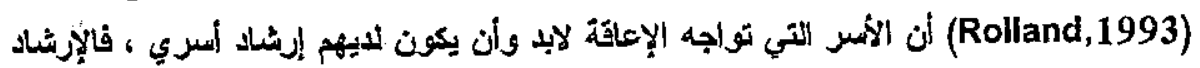

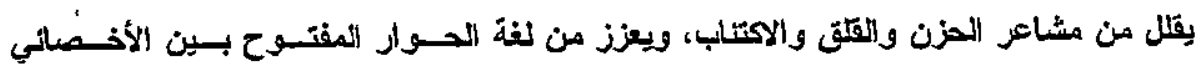

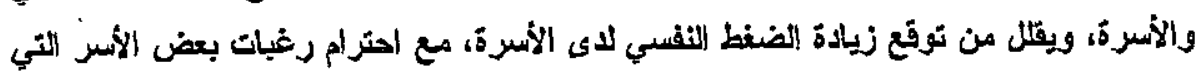
لا ترغب في الإزشاد.

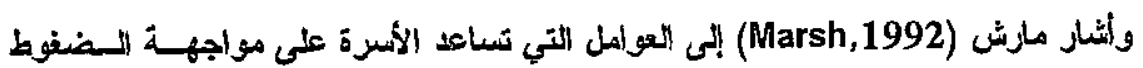

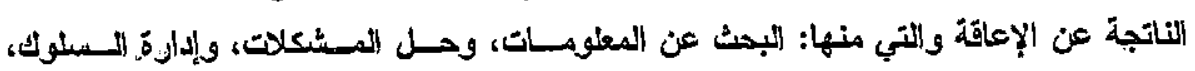

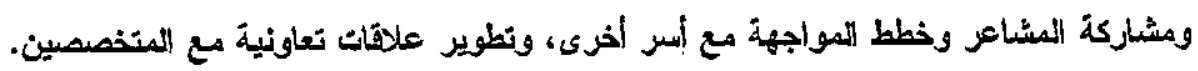

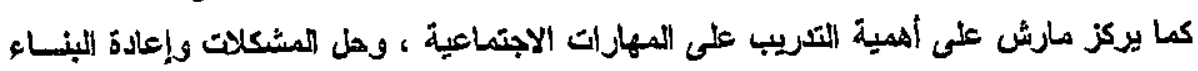

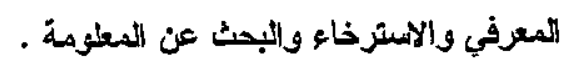

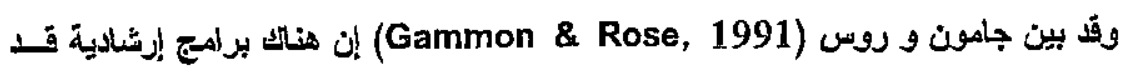

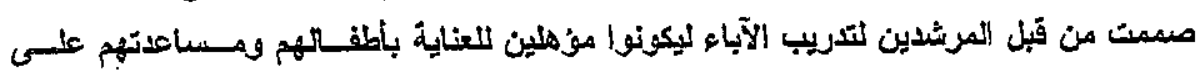

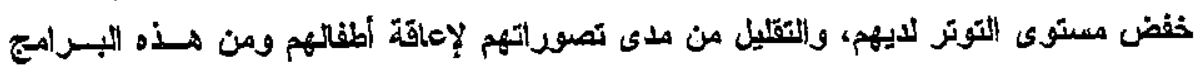
برنامج Coping Skills Training Program (CSTP) ويتضمن: إعـادة الثبنـاء

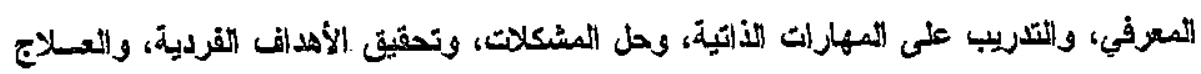
أو الإزشاد الجمعي. ومن الأساليب المؤدية لخفض الضغنوط طول ميكنبام (Meichnbaum) نموذجاً للتــريب

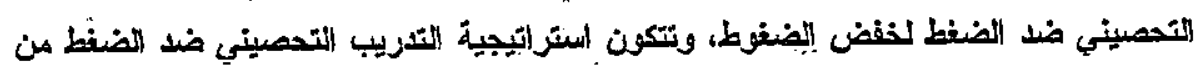

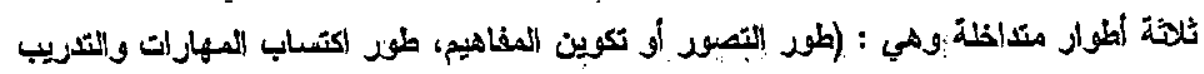

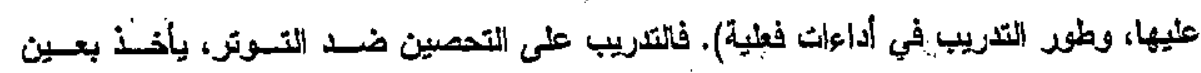

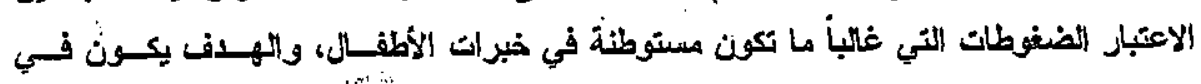

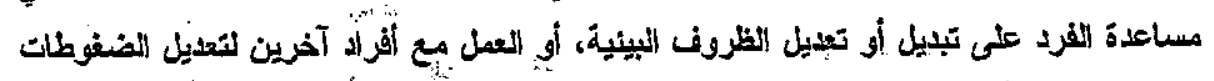

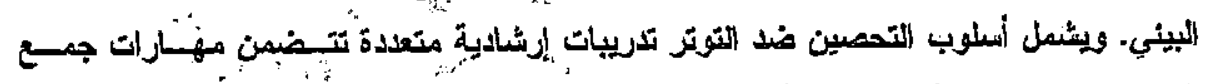

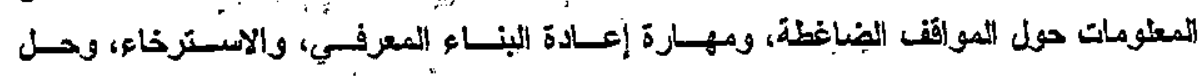
(المشكلات، والتشريب السلوكي (Clayton \& Ladd 2000 ; Meichnbaum,1996). 


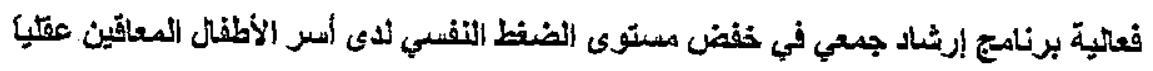

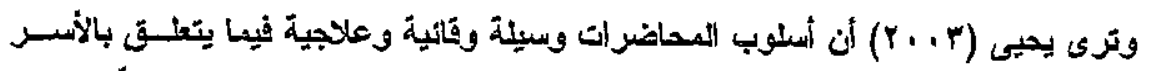

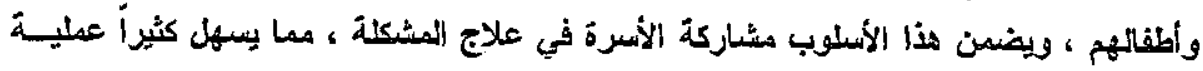

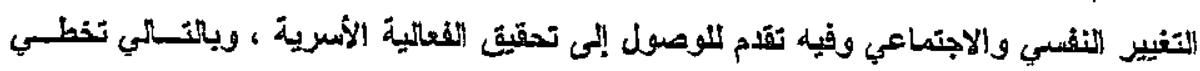

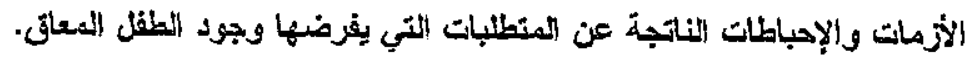

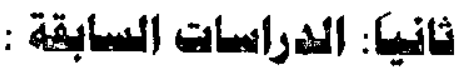

هن:

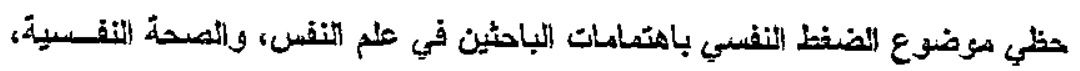

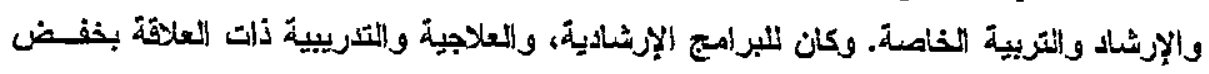

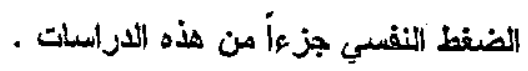

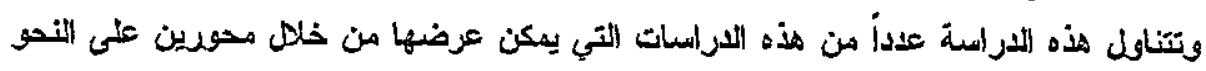
التالثي :-

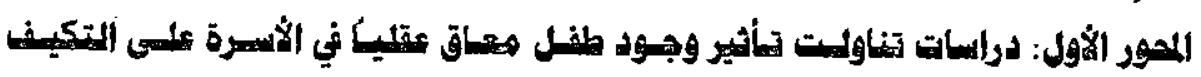

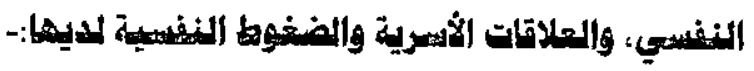

Singhi, Pershad, Singhi, Walia , أجرى سنجي و بيرشاد وبنجي ووانسيا

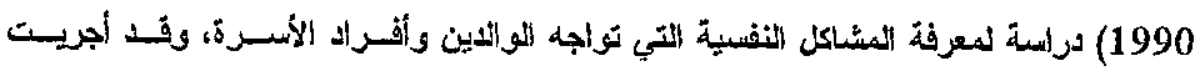

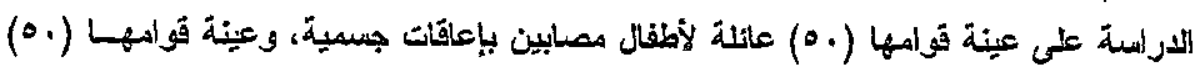

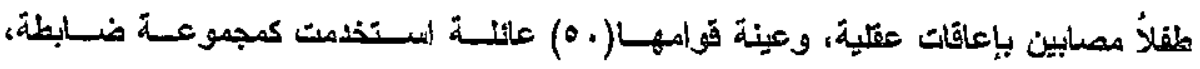

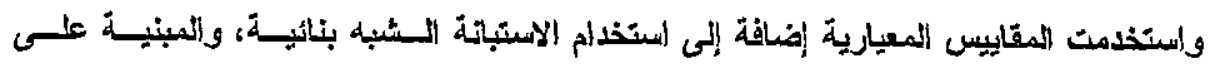

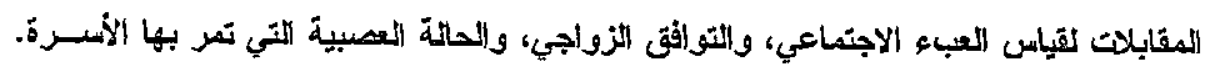

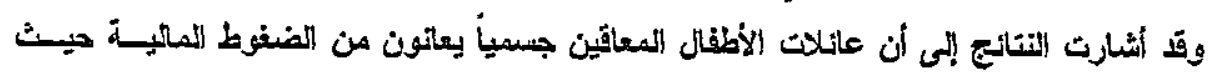

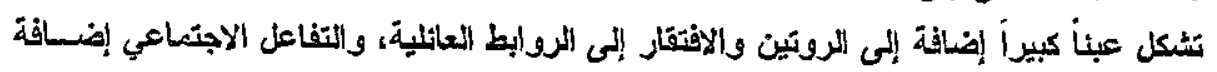

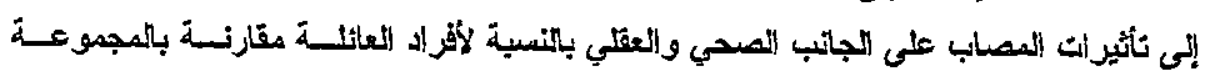

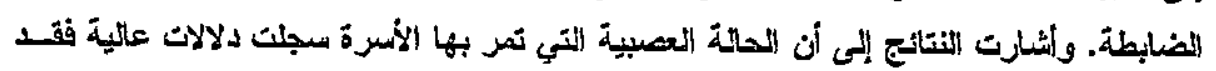

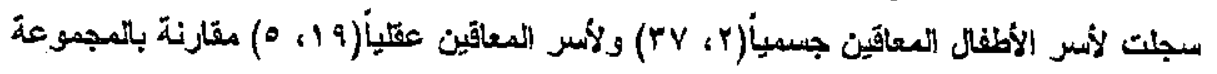

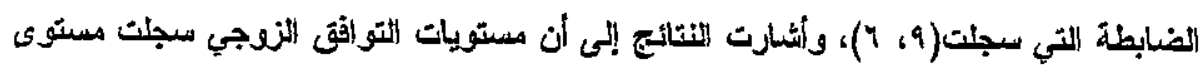

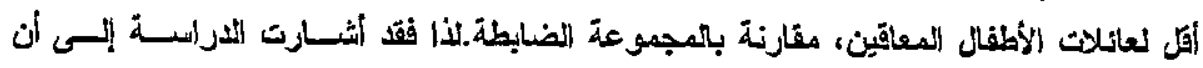

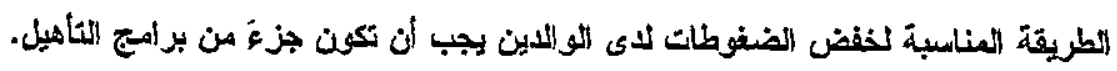


فعالية برنامج إرشّاد جمعي في خفض مسنتى الضغط النفسي لاى أسر الأطفل المعاقين عثليا

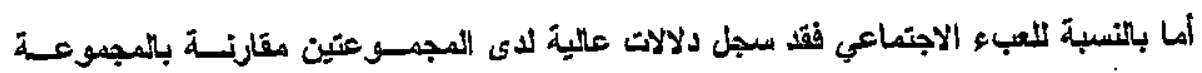

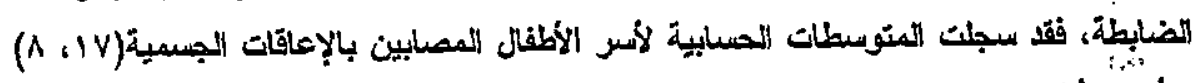

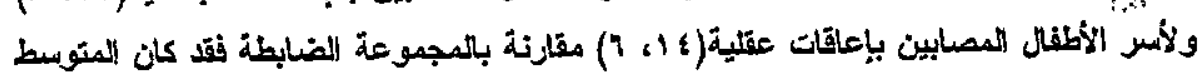

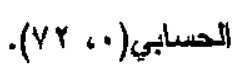

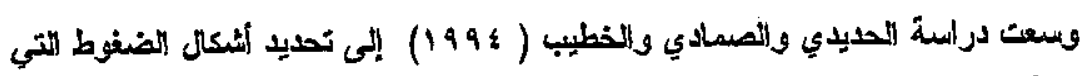

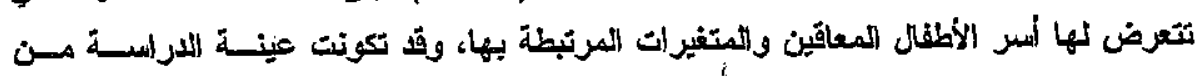

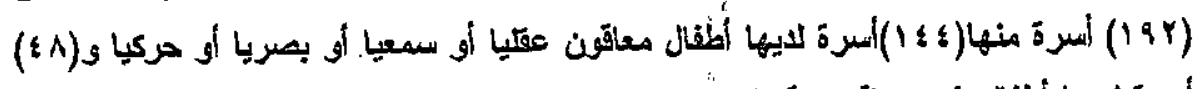

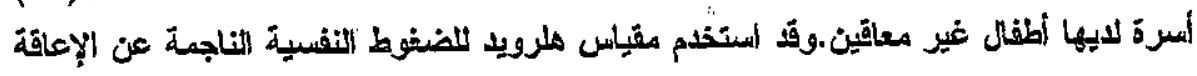

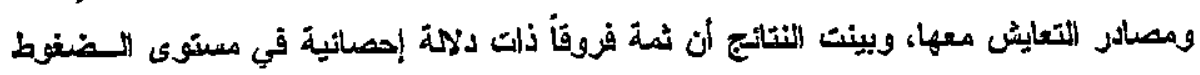

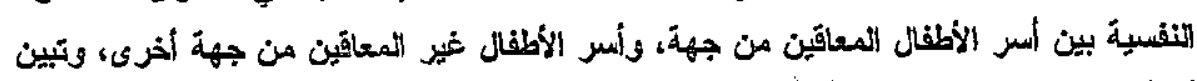

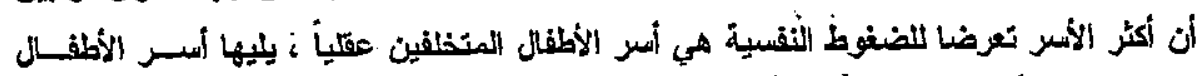

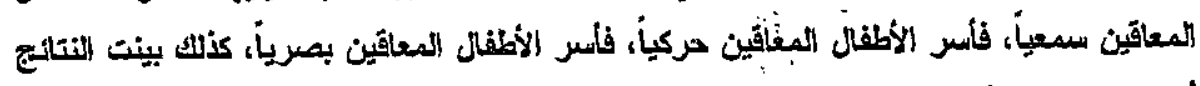

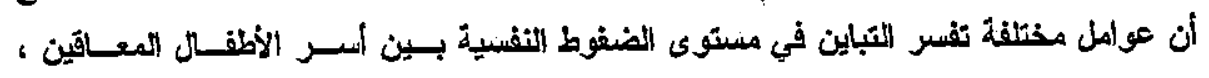

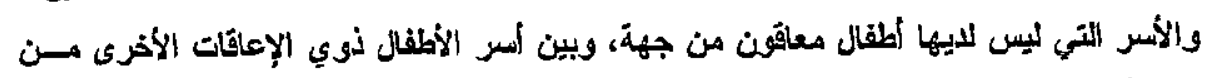
جهة أخرى.

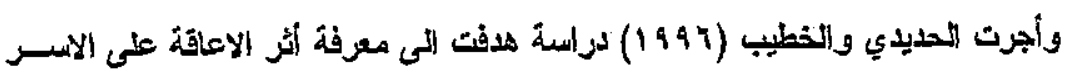

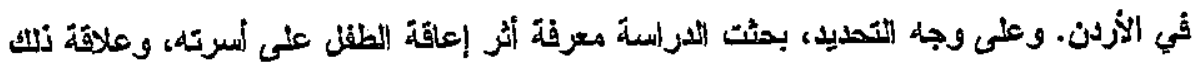

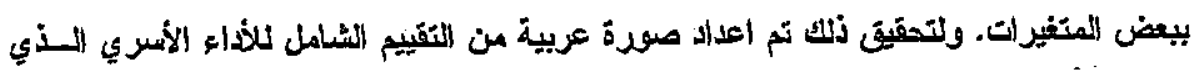

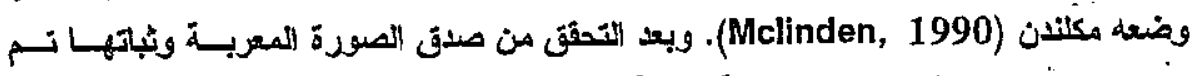

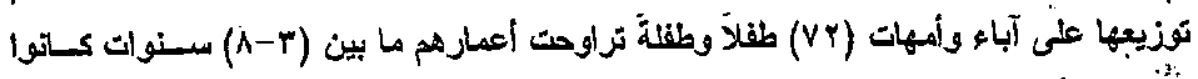

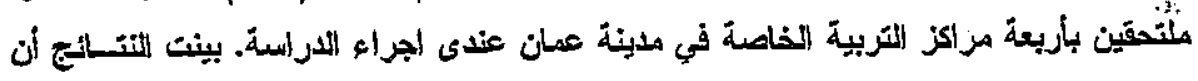

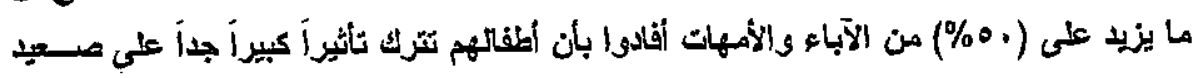

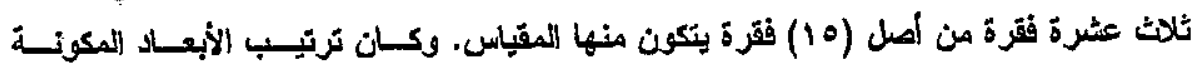

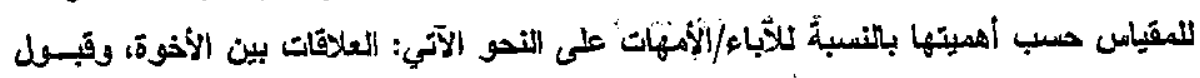

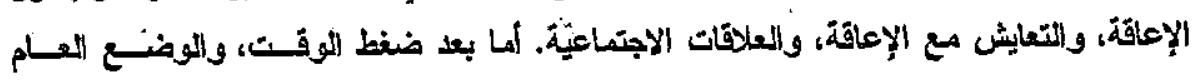

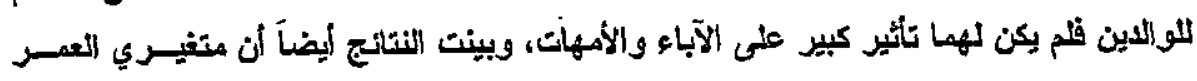

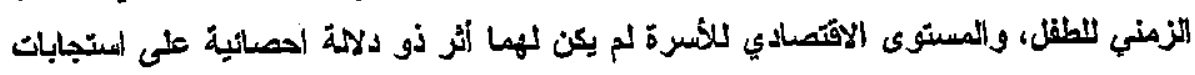
الآباء-والأمهاتث. 
فعاليةّة برناهج إرشاد جمعي في خفض دستوى الضغط النفسي لدى أسر الأطفال المعاثين عقليا وهافت دراسة كل من بـايني وسستونمان(Payane\& Stoneman, 1997) إلسى

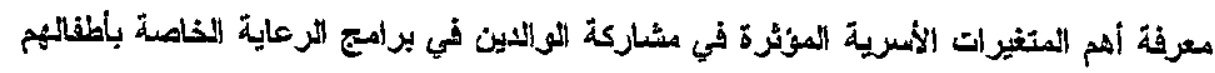

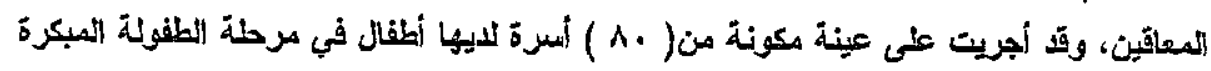

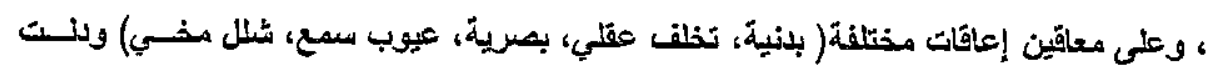

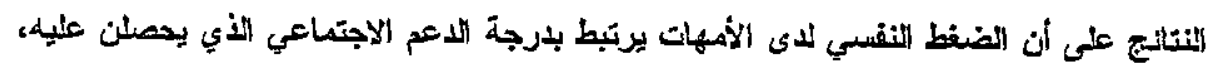

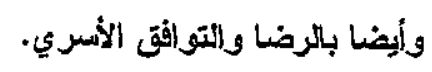

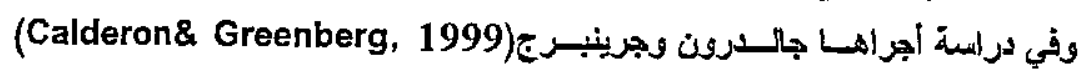

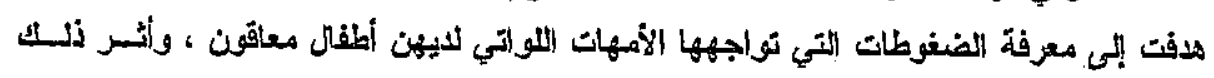

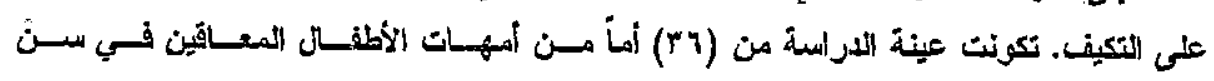

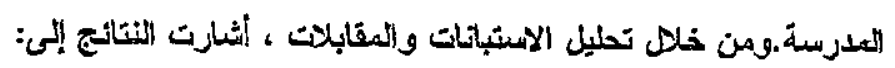

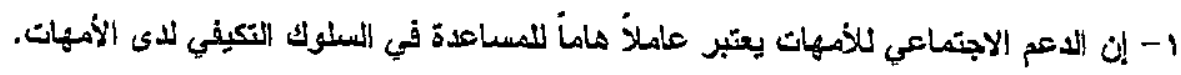
r- إن تزويد الأمهات بمهارات حل المثكلات ظهر كعامل ذي دلالة في تكيف الأمهات والأطفال.

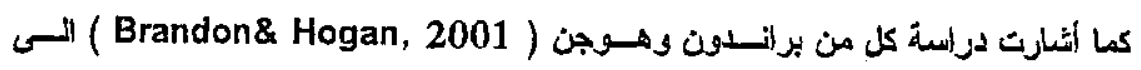

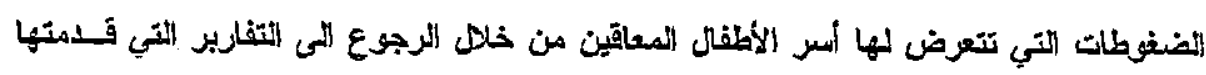

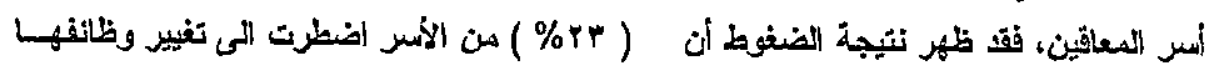

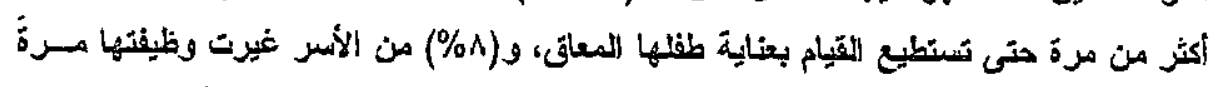

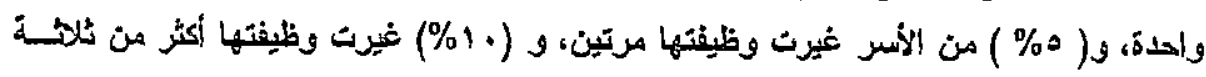

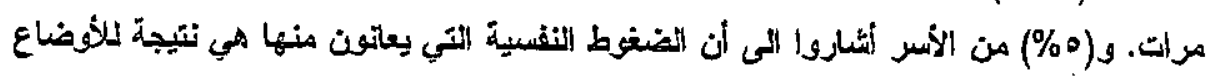

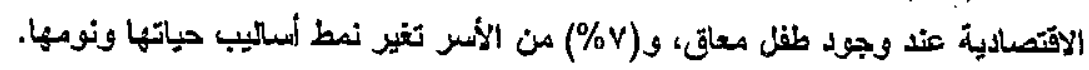

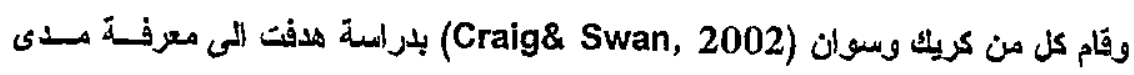

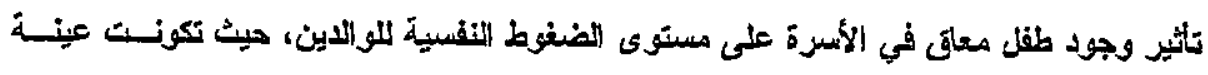

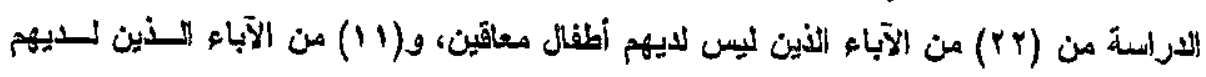

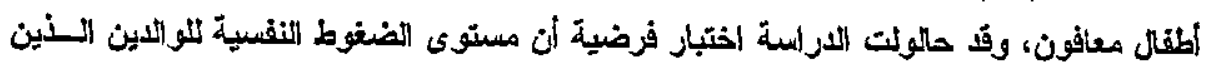

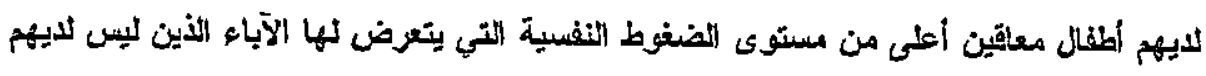

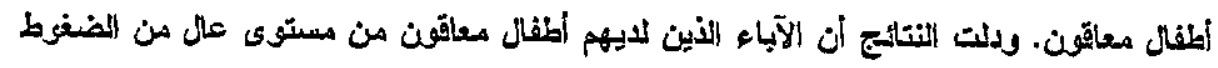

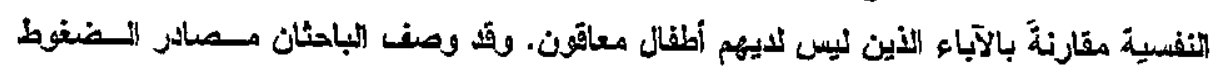

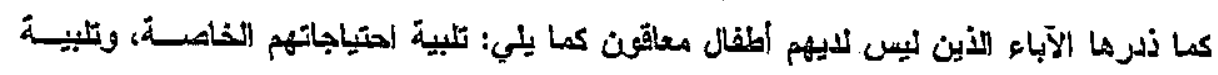

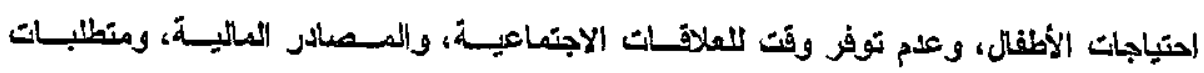

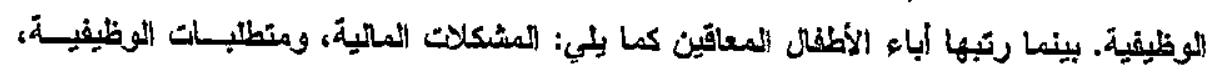


فعالمية برنامج إرشاد جمعي في خفض مستوىى الضنط النفسي لاى أسر الأطفال المعاقين عثليك

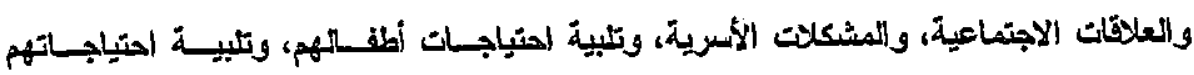
الخاصة.

وأجرى عبود (Abboud, 2003) دراسة هدفت إلى التمرفس على الضنوط اللنــسية

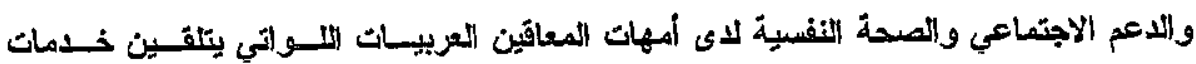

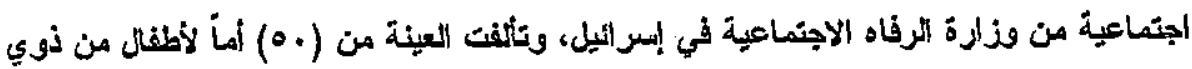

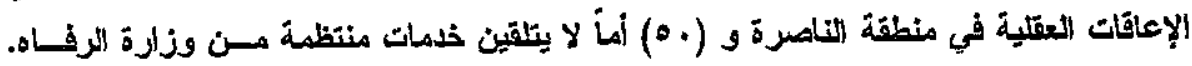

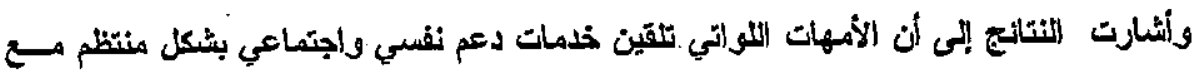

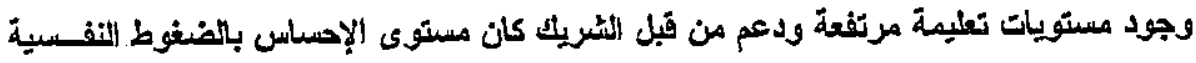

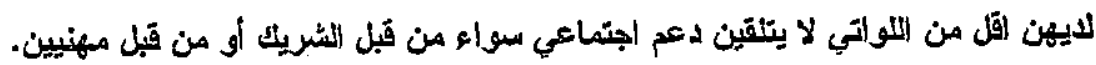

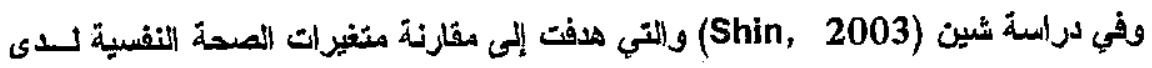

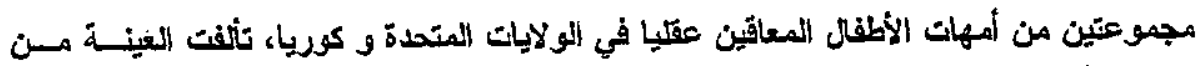

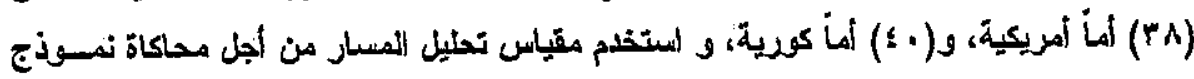

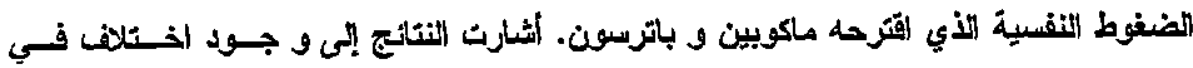

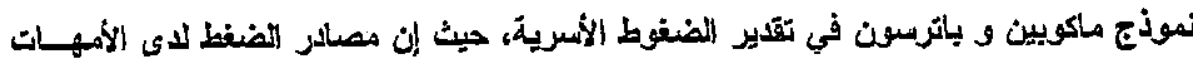

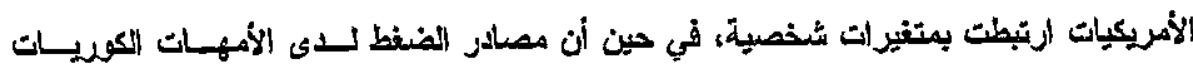
ارتبطت بالقيم الاجتماعية.

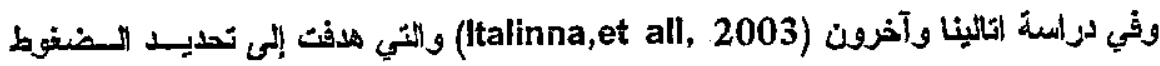

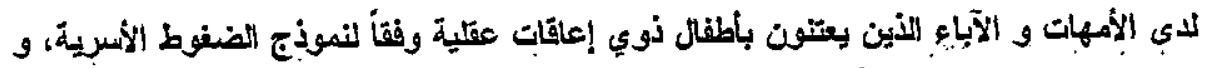

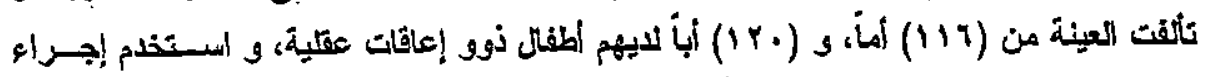

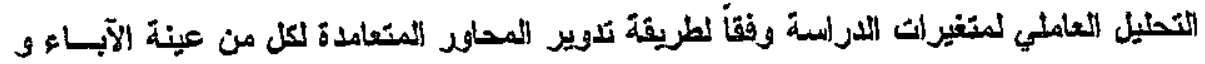

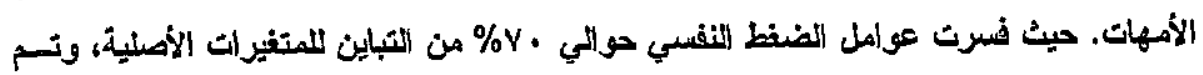

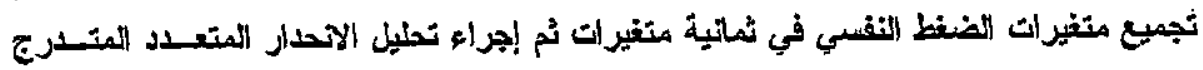

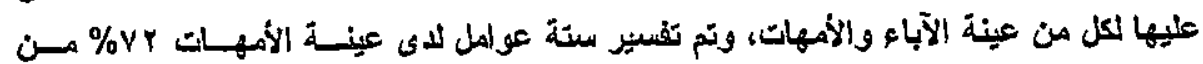

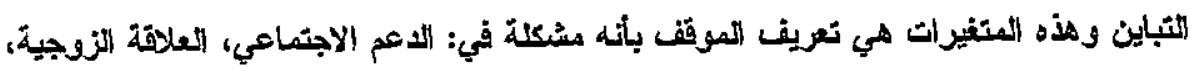

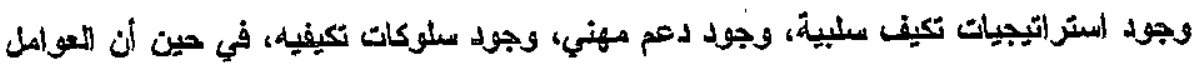

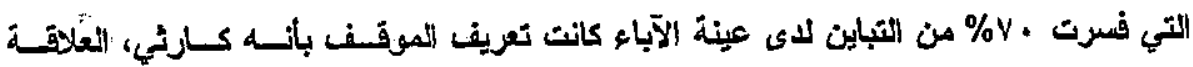

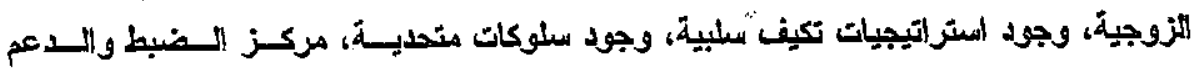
الاجتماعي، و للسنوكات التكيفية. 
فعالية برنامج إرئاد جمي في خهض مستوى الضغط النفسي لاى أسر الأطفال المعاقين عتليك

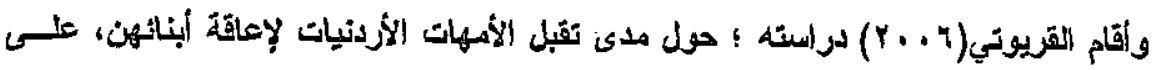

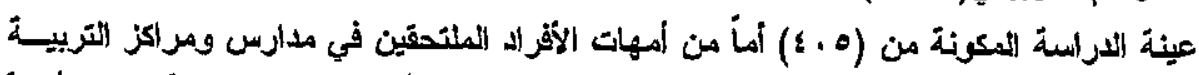

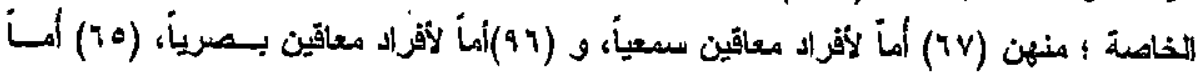

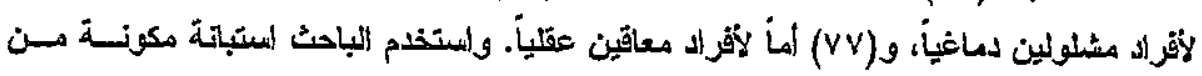

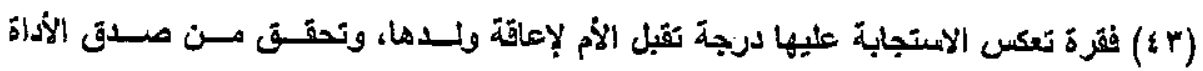

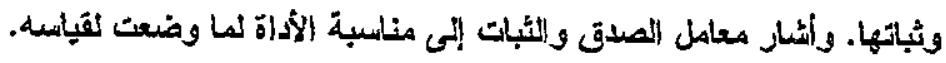

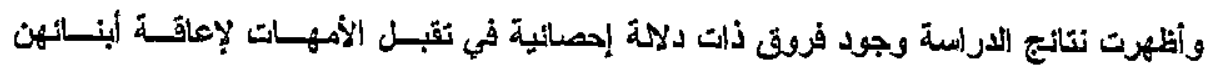

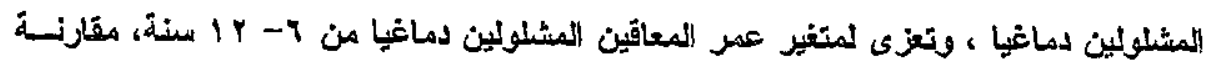

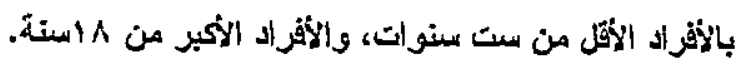

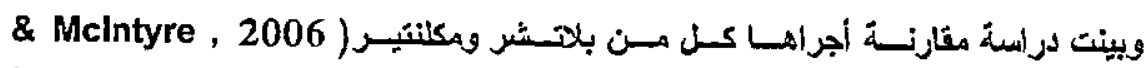

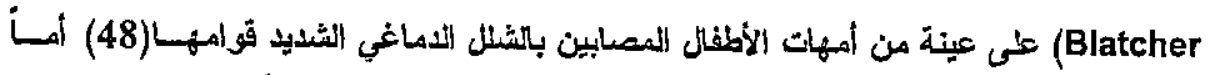

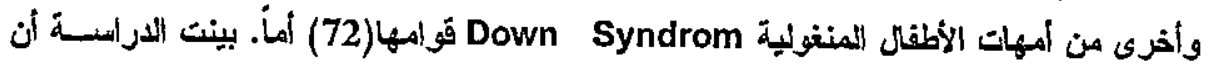

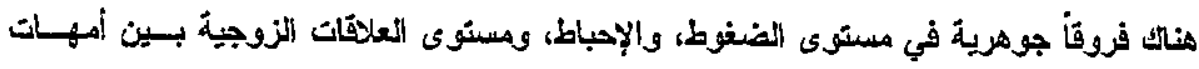
الأطفال المصابين بالشلل الدماغي، وأمهات الأطفال المنغوليين وبينت الأنتائج أن أمهاتت الأطفال

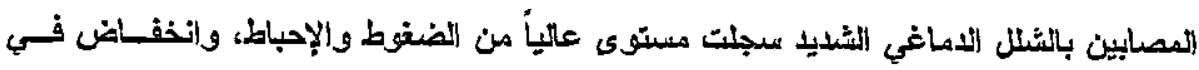

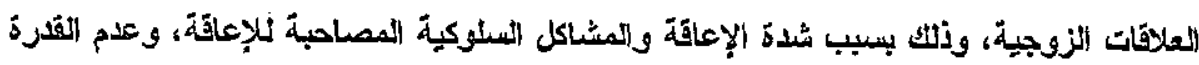

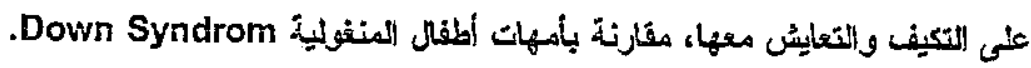

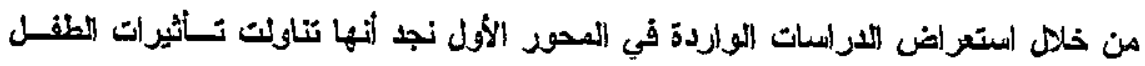

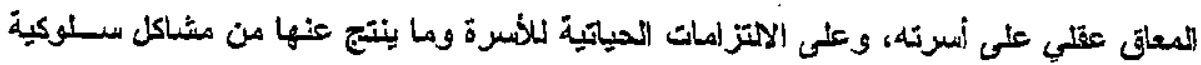

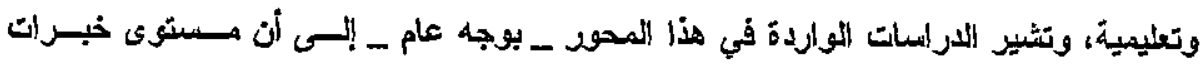

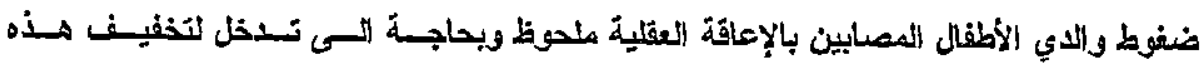
الاضفوطات.

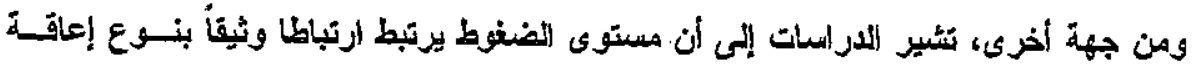
المطقل وشدتها.

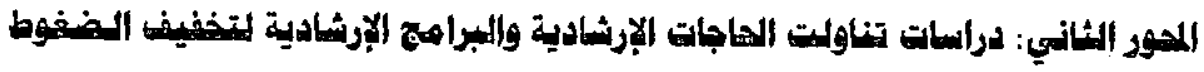

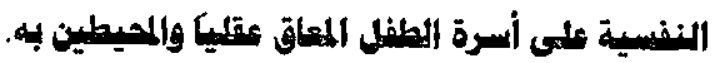

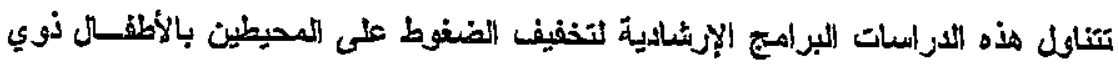
الإعاقةة العقلية. 
فعالية برنامج إرشاد جعي في خفض مستوى الضغط النقسي لدى أسر الأطفال المعاقين عقليا

أجزى براون ( Brawn, 1980 ) دراسة بعنوان فاعلية التدريب على مهارات المواجهـة

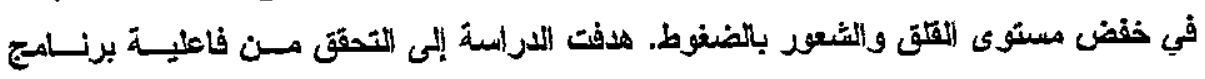

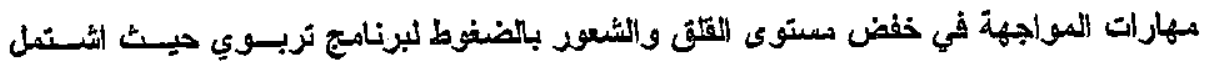

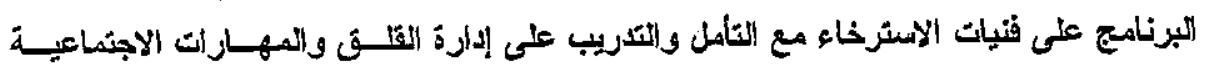

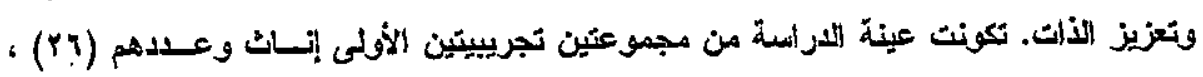

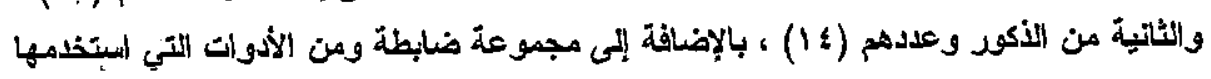

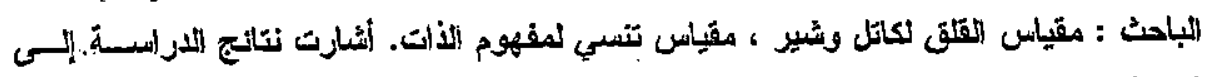

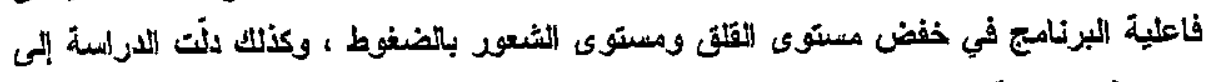

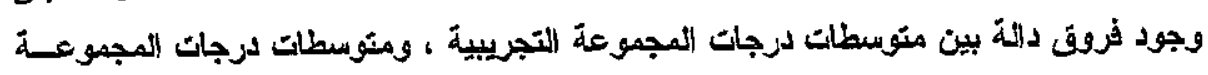

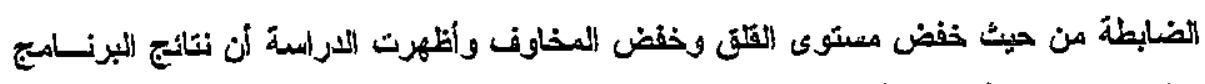

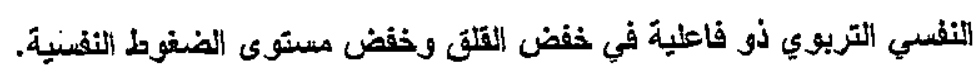

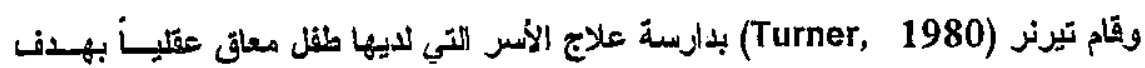

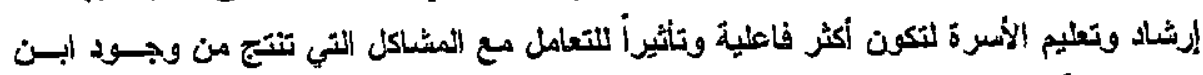

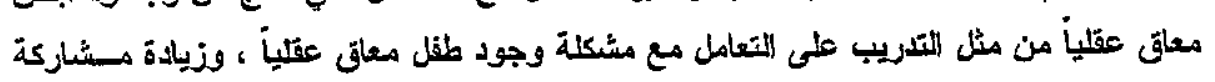

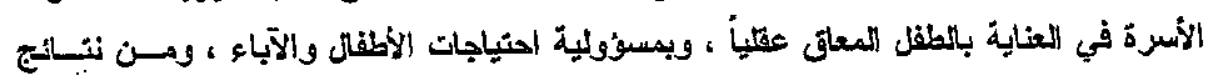

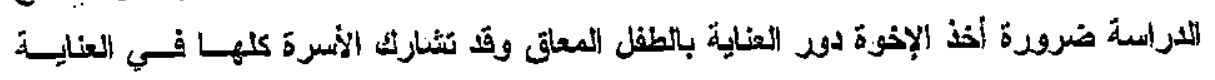

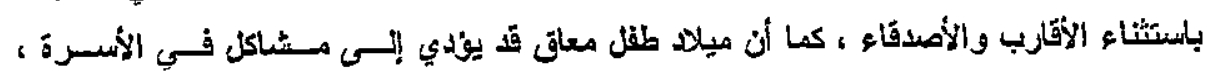

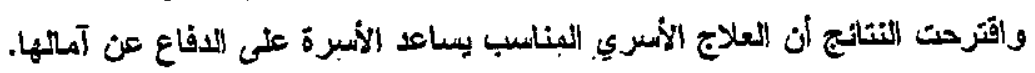

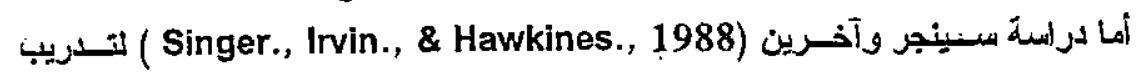

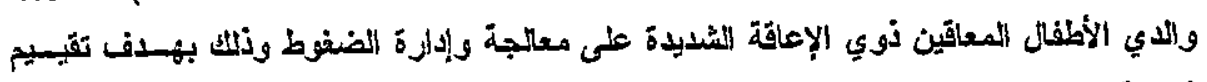

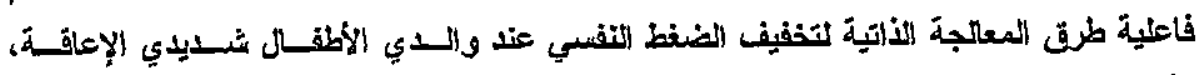

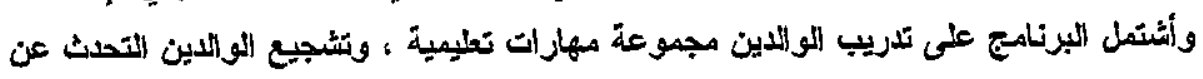

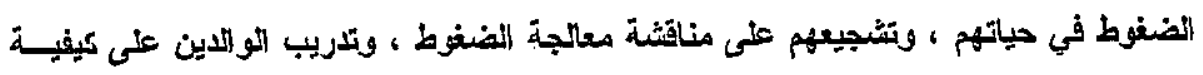

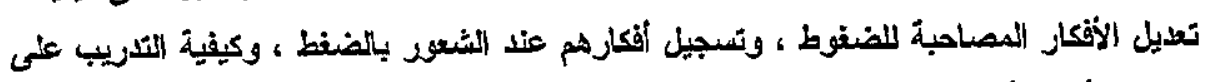

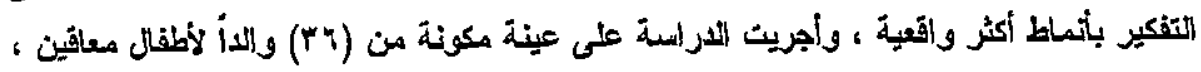

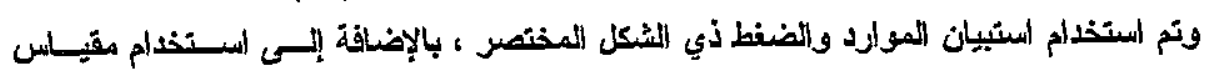

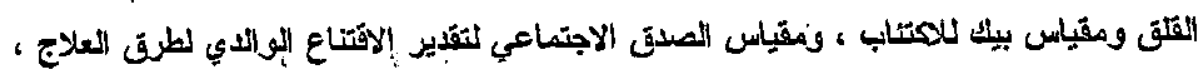

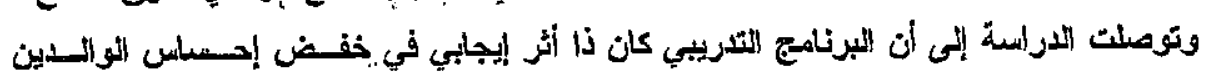

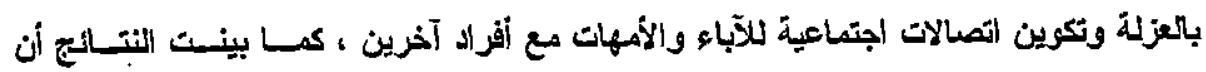


فعالية برنامج إرشاد جمي في خفض مستوى الضغط إلنفسي لاى أسز الأطفال المعاقيّن عثليا

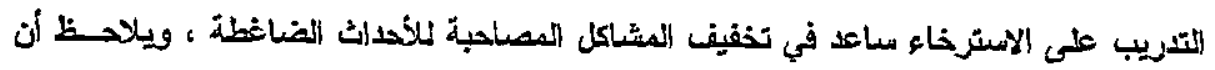

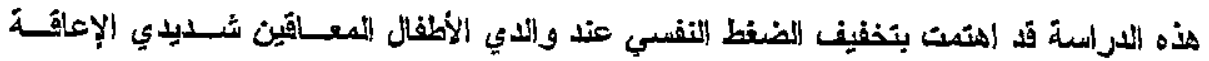

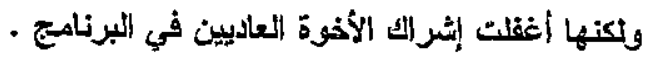
وأجرت جامون ودوس (Gammon \& Rose, 1991) دراسة هلفت إلى التحقى مسن التين

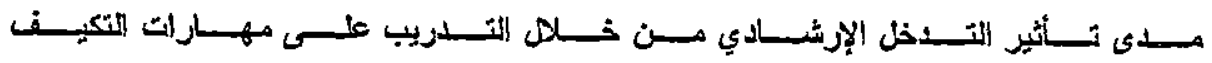
(Coping Skills TrainingProgram)

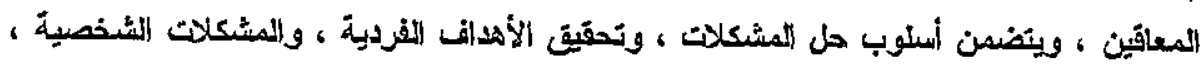

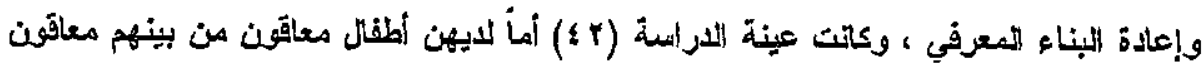

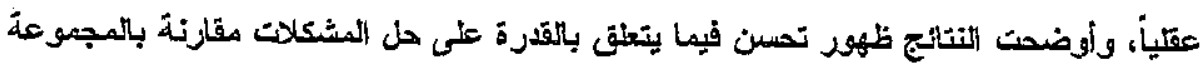

$$
\text { التي لم تخضع للتنريب . }
$$

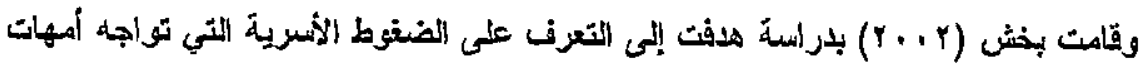

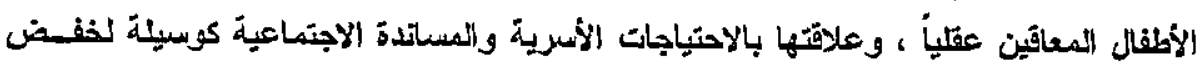

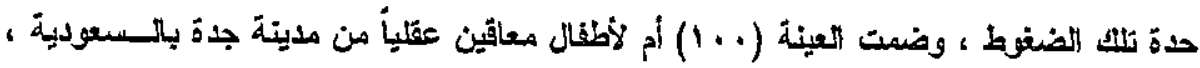
وتم استخدام مقياس الضفوط لأمهات الأطفل المعاقين عقلياً ، ومقياسل احتياجات أولئياء أمسيهد

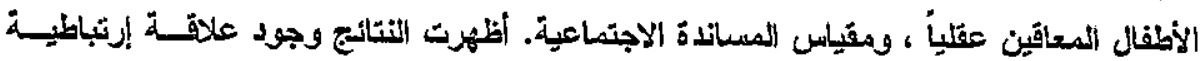

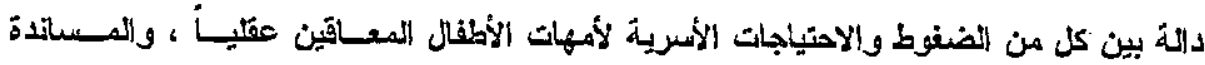

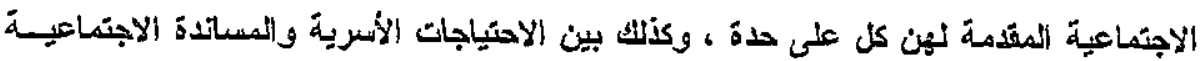

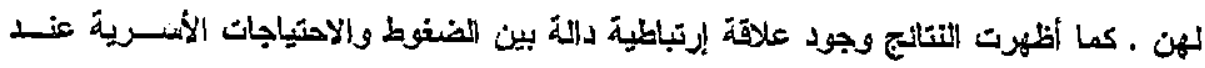

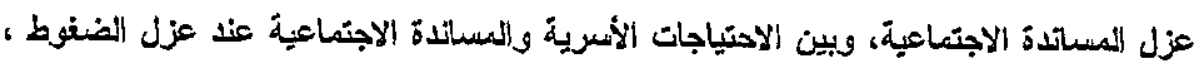

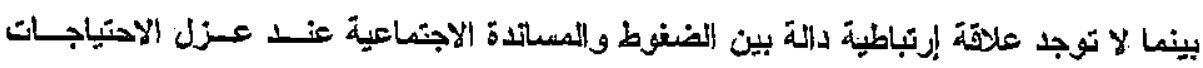
الأسرية.

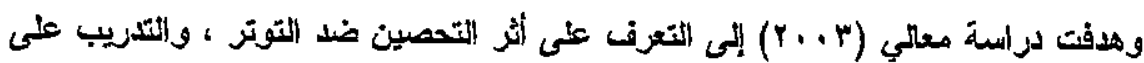

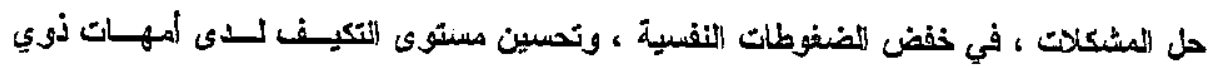

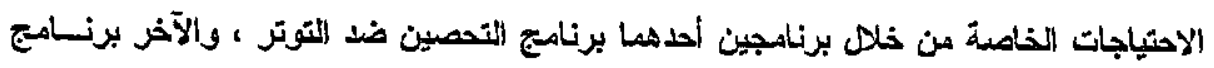

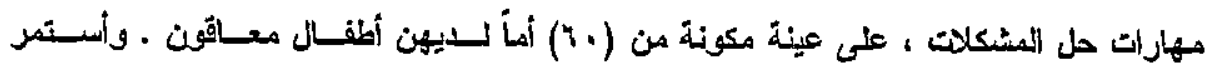

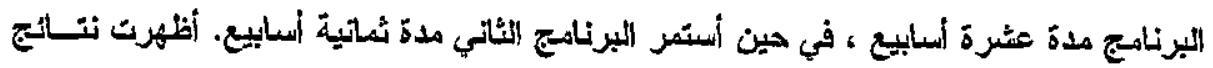

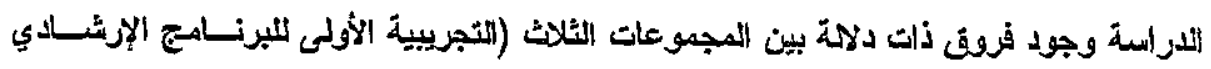

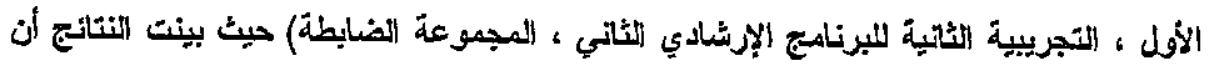

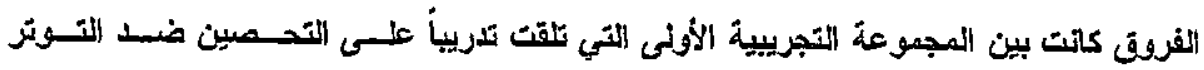


فعالية برنامج إرشاد جمعي في نخضض مستوى الضفط النفسي لاى أسر الأطفال المعاقين عقليا

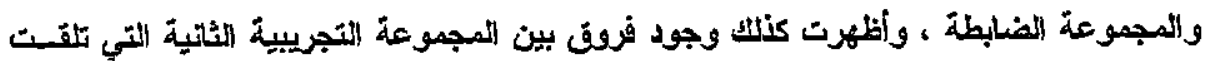

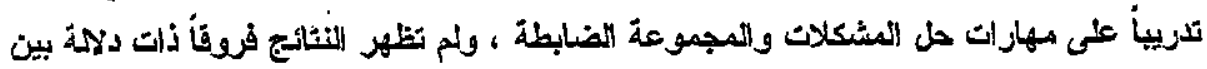

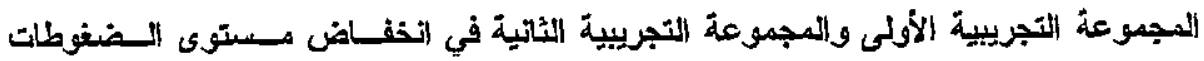
النفسية وتحسين مسنوى التكيف للأمهات.

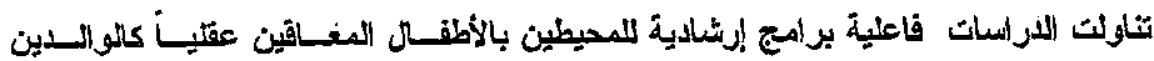
، (Gammon \& Rose, 1991) و والآباء (Singer., Irvin., \& Hawkines., 1988 )

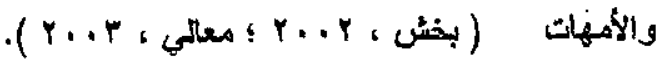

$$
\begin{aligned}
& \text { المكريقة والإبماكاتt: }
\end{aligned}
$$

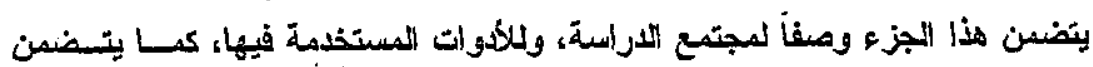

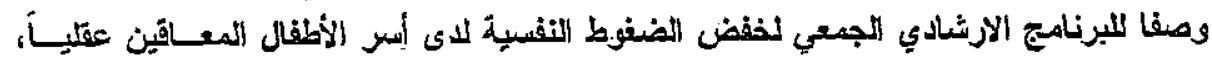

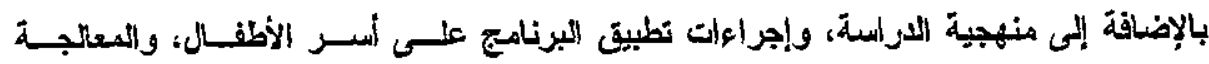
الإحصائية.

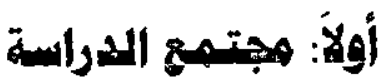

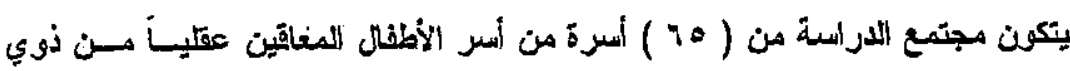

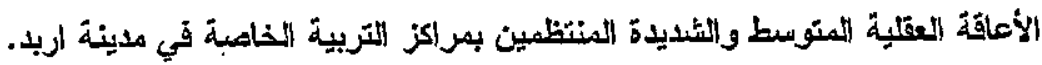

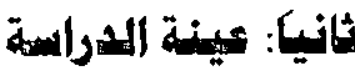

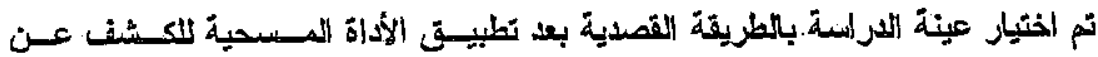

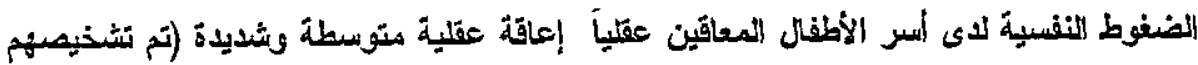

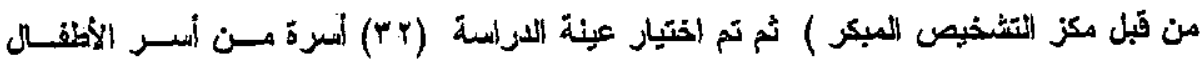

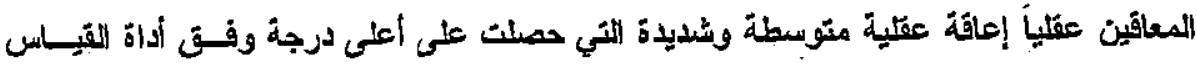

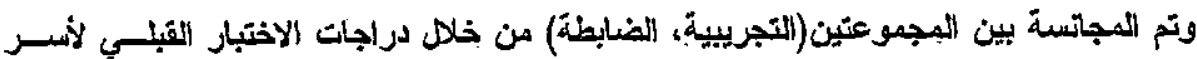

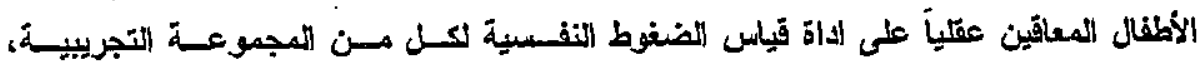
والمجموعة الضضابطة.

وتم توزيع أفراد العينة بالطريقة العبوائية إلى مجموعتين تجريبية وضابطة، بحيث تكونت كـل

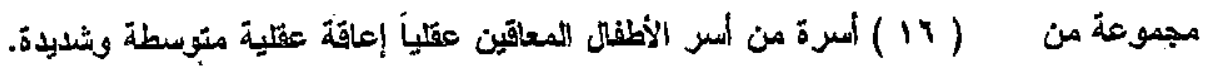
ويبين جدول رقم (1) توزيع أطفال الأسر المعاقين عثلياً حسب الجنس.

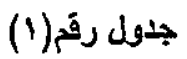


فعالثية برنامج إرشاد جمعي في خفض مستوى الضغط التفسي لدى أسر الأطفال المعاقين عقليا توزيع أطفل الأسب أقرالد الادراسة حسب الجنس ( تجريبية :وضابطة )

\begin{tabular}{|c|c|c|c|}
\hline المجموع & إنات & ذكور & \\
\hline 17 & $\wedge$ & $\wedge$ & تجريبية \\
\hline 17 & 9 & $v$ & ضابطة \\
\hline rY & iv & 10 & المجموع \\
\hline
\end{tabular}

وييين جدول رقم (Y) توزيع أطفال الأسر المعاقين عقلياً حسب درجة الإعاقة. الجدول رقم (r)

تتزيع أطفال الأسبر أفر الد الدراسة حسب متغير لرجة الإعاقَة (متونسطة ، شنديدة)

\begin{tabular}{|c|c|c|c|}
\hline المجموع & شُديدة & متوسطة & مة الإعاقة \\
\hline 14 & 7 & 1. & تجريبية \\
\hline 19 & $v$ & 9 & ضابطة \\
\hline rY & 14 & 19 & المجموع \\
\hline
\end{tabular}

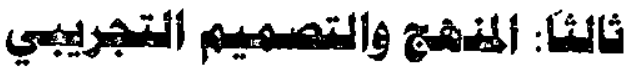

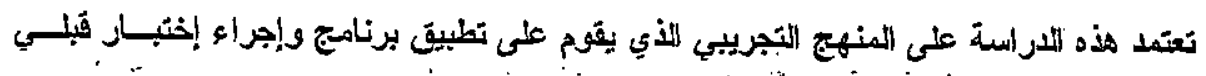
ويعذي للمجموعنين الأتجريبية وإلضابطة.

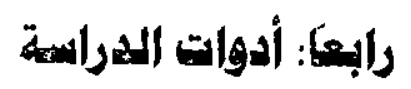

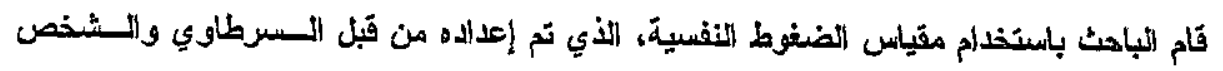

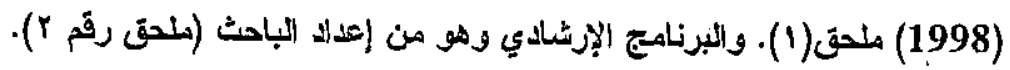

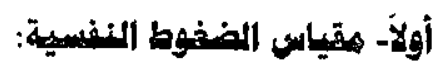

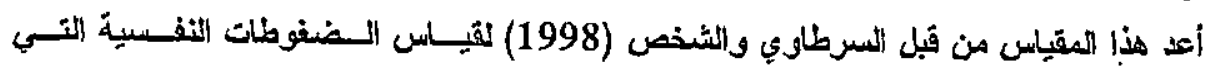

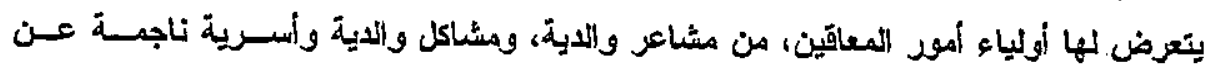

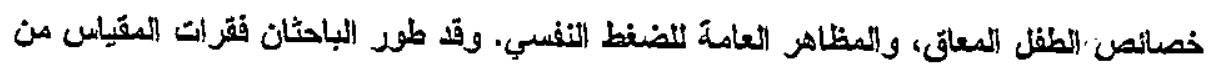

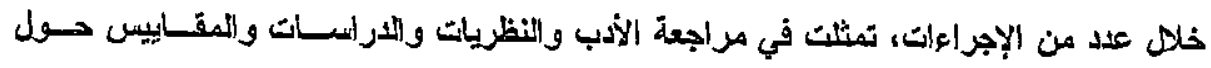
الضغويط النفسية بشكل عام وكنلت المتعلقة بالإعاقة. 


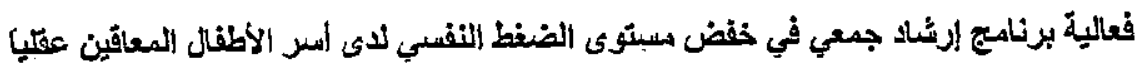
ويذكر السرطنوي والثُخص أن المقياس يتكون من سبعة عوامل لقياس الضغوط النفسية، هي:

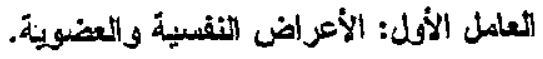

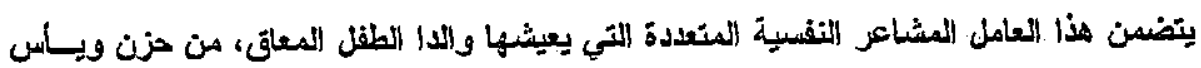

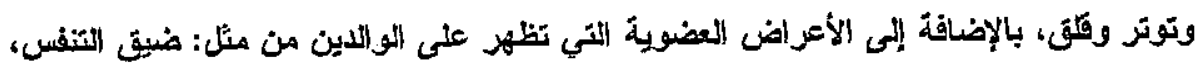

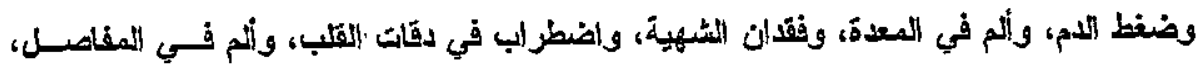

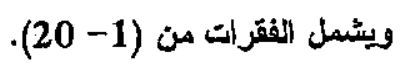

العامل الثئني: مشاعر اليأس والإحباط.

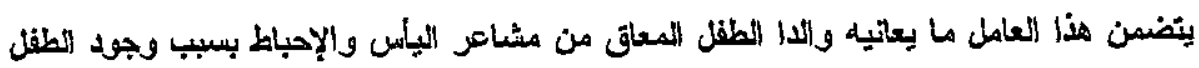

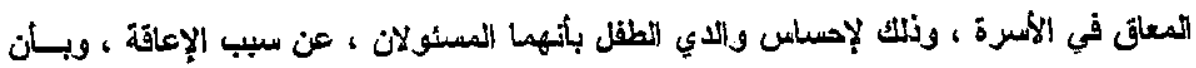

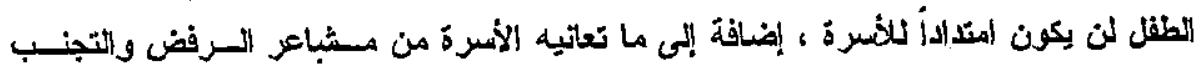

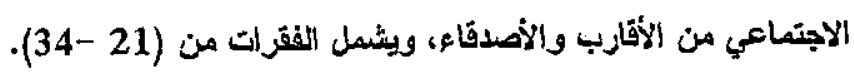

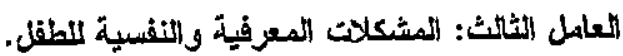

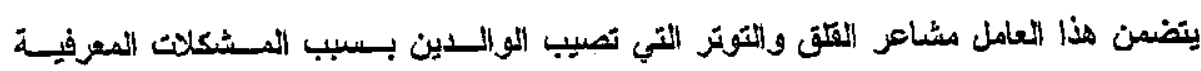

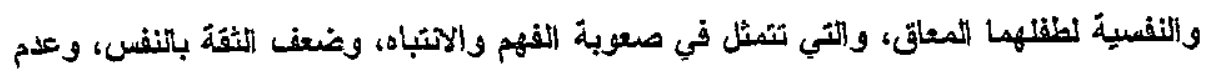

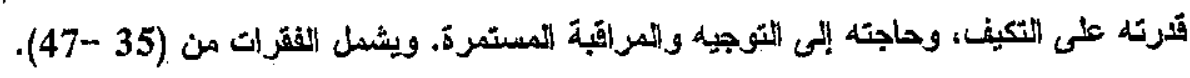
العامل اللرابع: المشكلات الأسرية الاجتماعية.

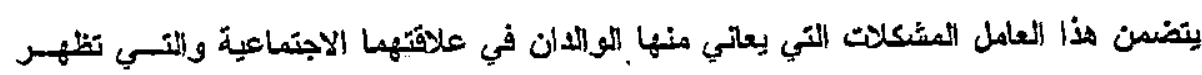

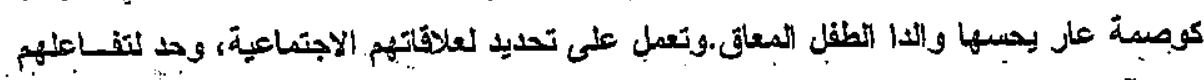

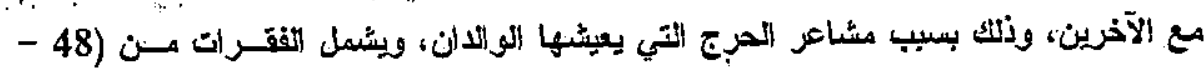

العامل الخامس: القتى على مسنقبل الطفل.

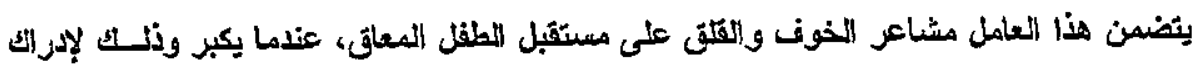

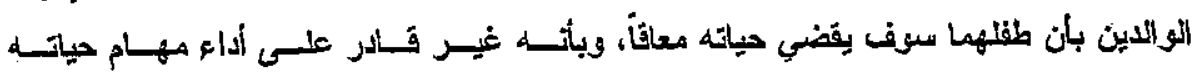

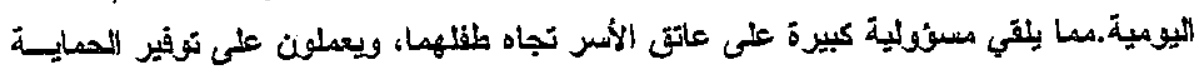

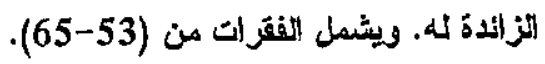

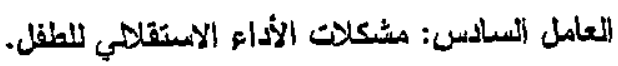

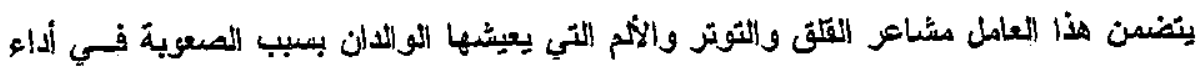

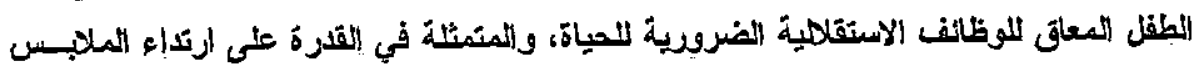

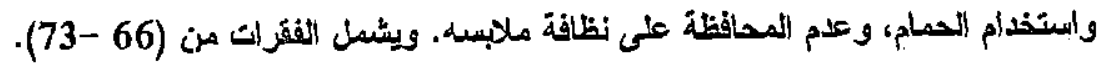


فعلية برنامج إرشاد جمعي في خفض مسنوى الضنط المفسي لدى أسر الأطفال المعاقين عقليا العامل العابع: عدم القدزة على تحمل أعباء الطفل.

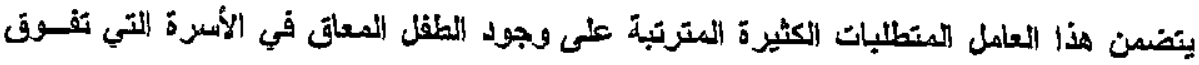

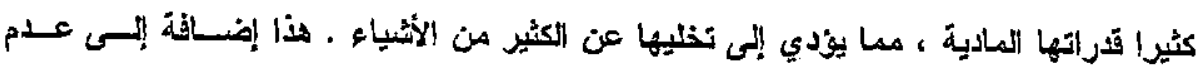

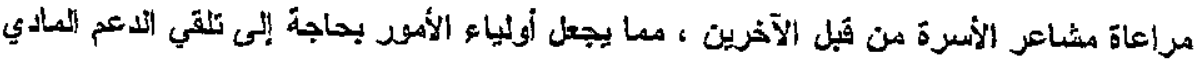

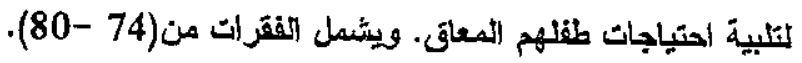

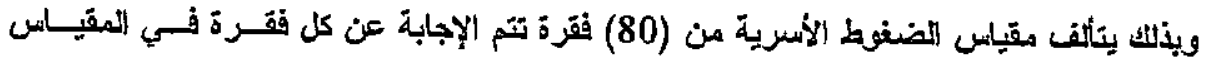

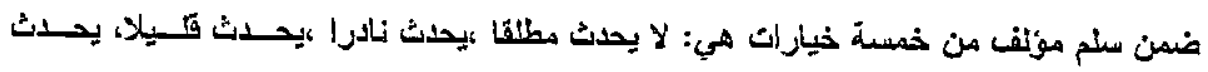
كثيرا، يحدث دائما.

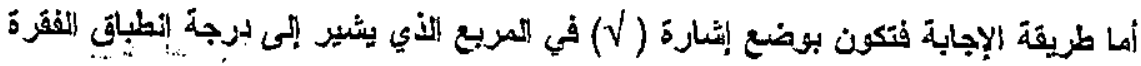

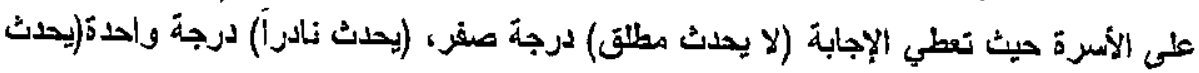

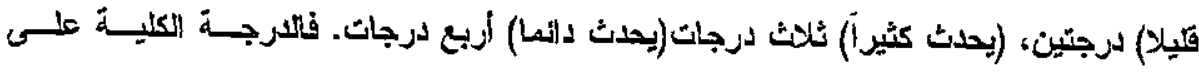

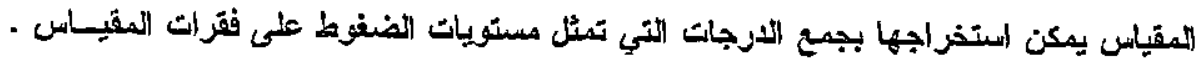

$$
\text { وتترائح الارجة على المقياس من (80-320). }
$$

\section{هندق الهقياس واثباتهي:}

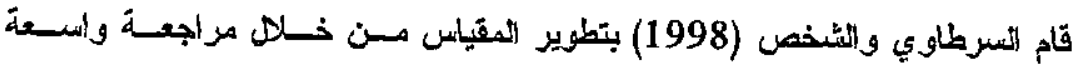

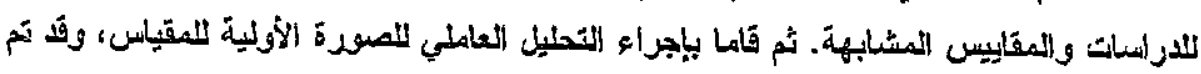

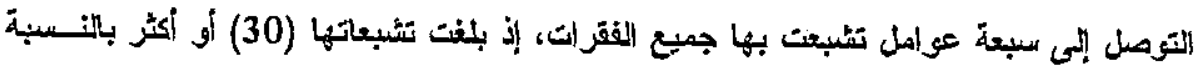

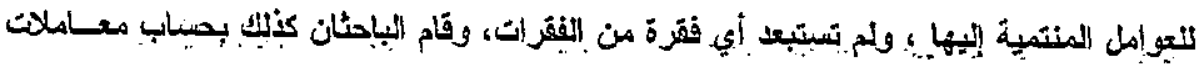

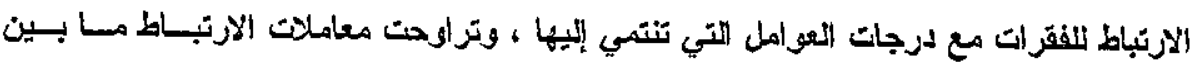

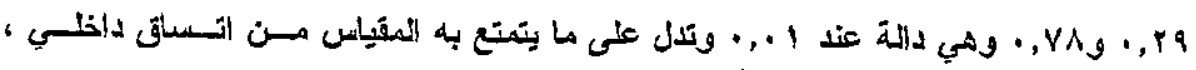
ويعتبر ذنك مؤشرأ على صدق المقياس.

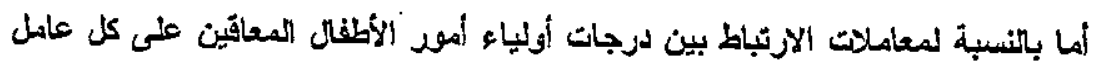

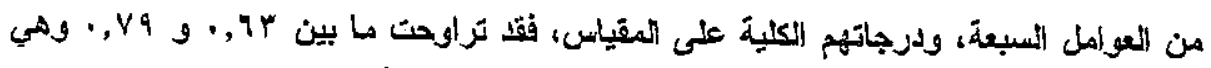

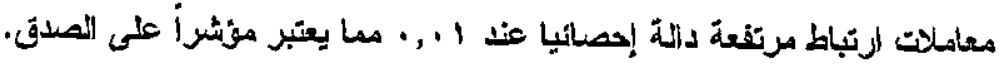

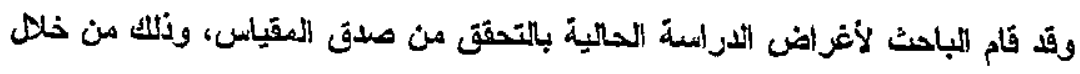

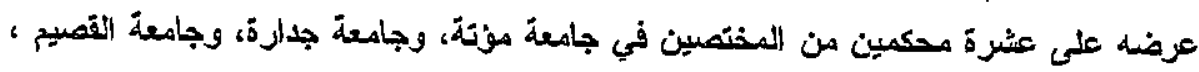

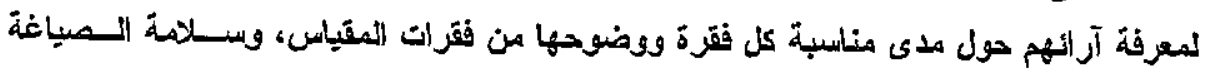

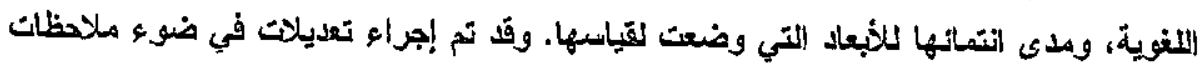

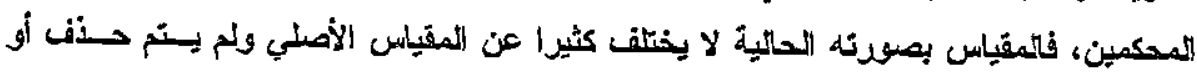


فعالية برنامج إرشاد جمعي في خفض مستوى الضنط النفسي لدى أسر الأطفال المعاقين عقبيً

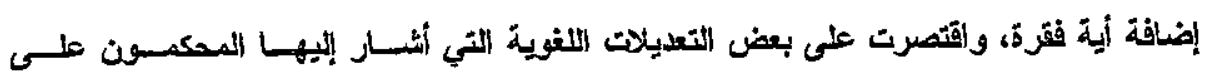

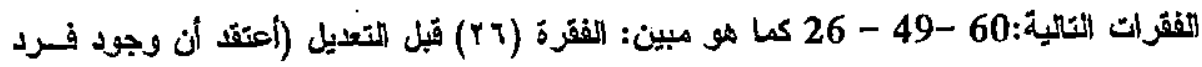

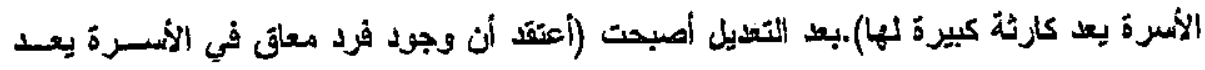

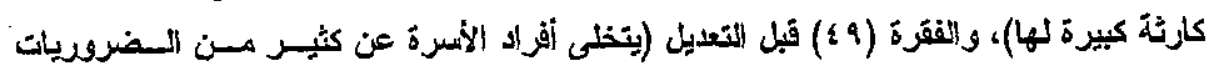

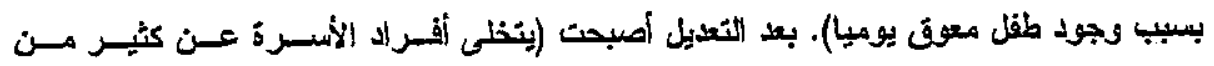

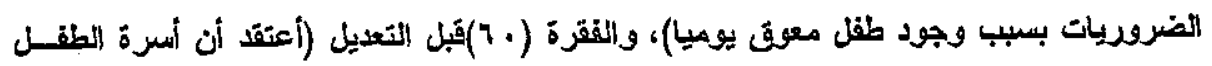

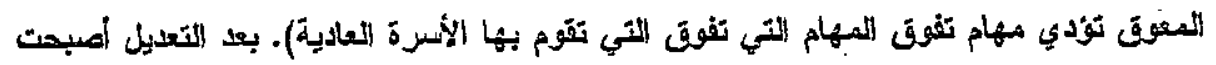
(أعتقد أن وجود فرد معاقى في الأسرة يعد كارئة كييرة لهبا).

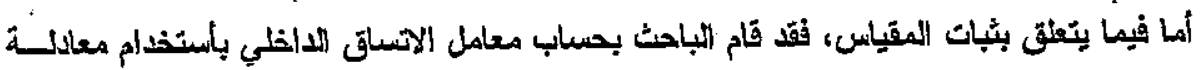
كرنباخ ألفا لجميع أفراد العينة حيث كان الثبات ( وقابلة للتطبيق لغايات اللاراسة الحائية.

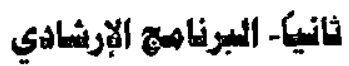

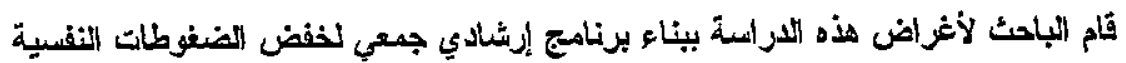

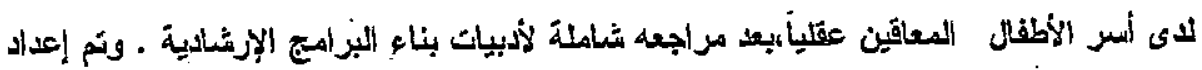

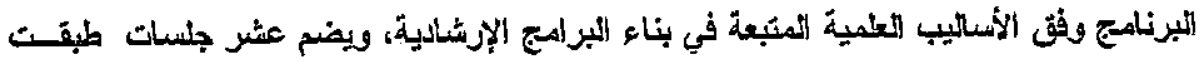

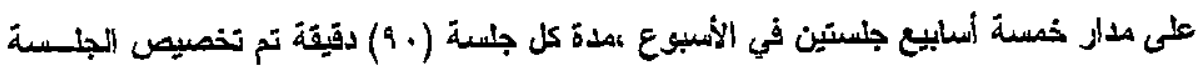

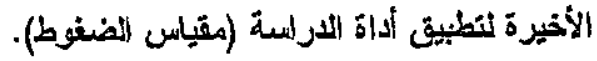

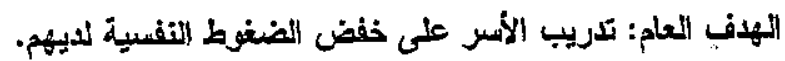

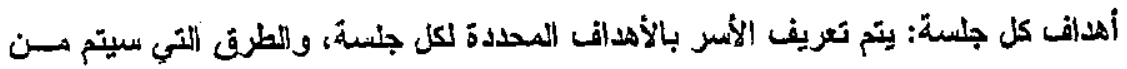
خلالها تحقيق الأهداف. وقام الباحث بالتحقى من صلتى وصلاحية البرنامج الإرشادي لخفض الضغنوط النفسية لاى

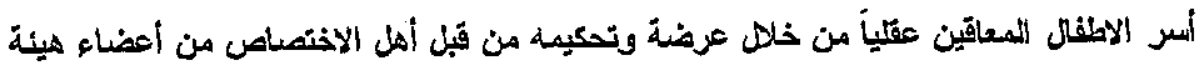

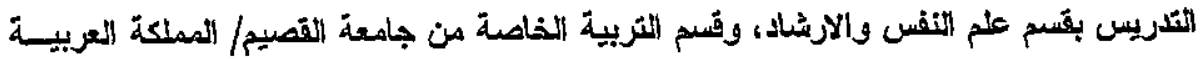

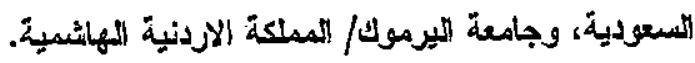

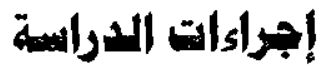
ا- قام الباحث بتطبيق مقياس الضنوط النفسية على أسر الاطفال المعاقين عقليـأ الملتحقـين

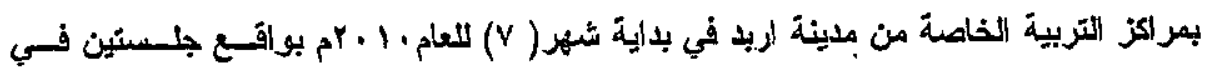

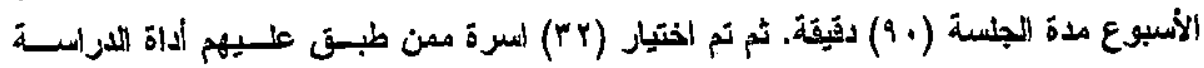


فعالية برنامج إرشاد جمعي في خفض مستوى الضنط النفسي نلاى أسر الأطفل المعاقين عقليا الحاصلون على أعلا درجة بعد تطبيق الاختبار القبلي على الداة الاراسـة (مفيساس الـضضغط

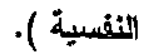

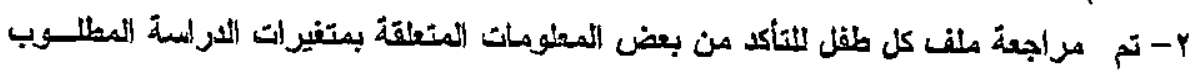

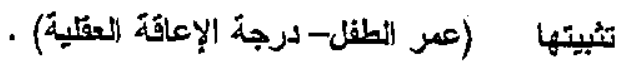

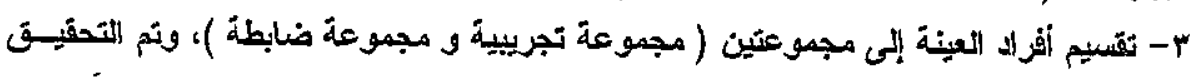

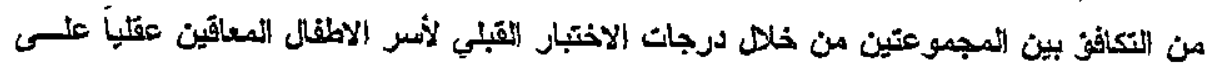

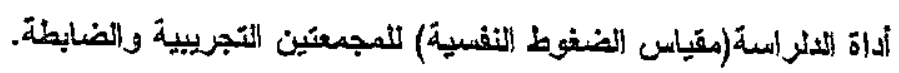

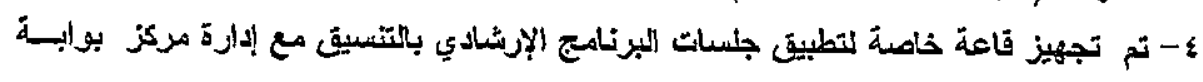
الثيرموك.

ه- تصميم الخطة الإرشادية بأهدافها المرحلية ، والمدة الزمينية المناسبة لكل مرحطة .

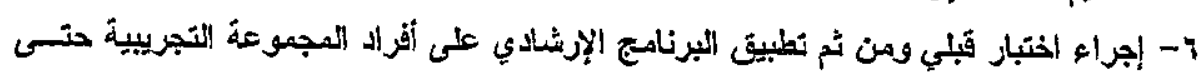
الوصول إلى اكتمال الجنسات الإرشادية.

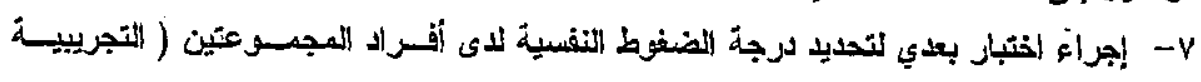

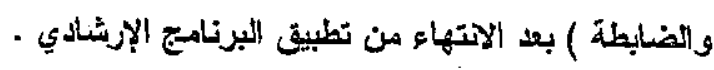

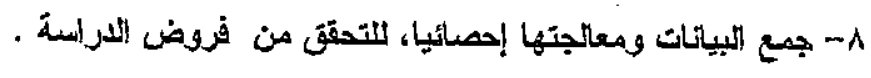

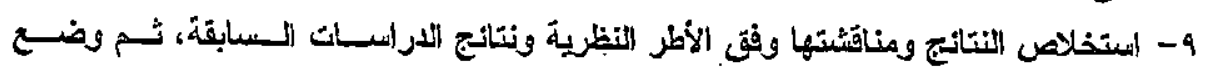
التوصيات .

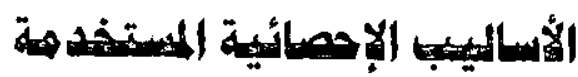

اللتحمقي من صحة فروض الار السة تم الستخدام الأساليب الإحصائية التالية:

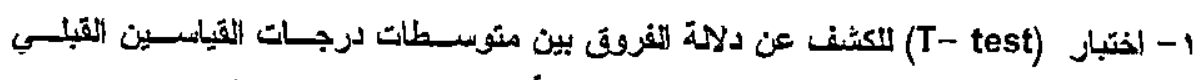

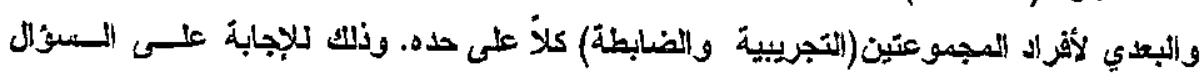
الأول

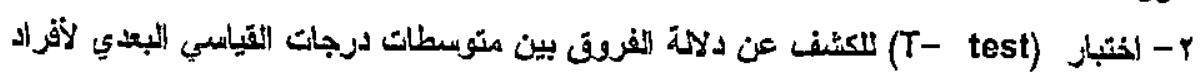
المجمو عتين(التجريبية)، وذلتك للإجابة على السؤال الثاني.

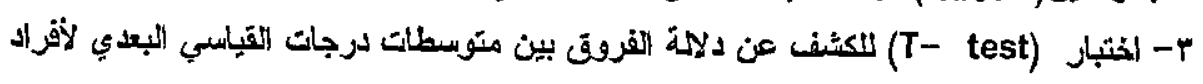

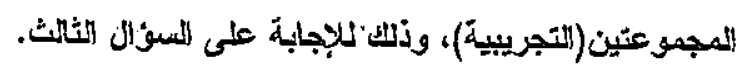

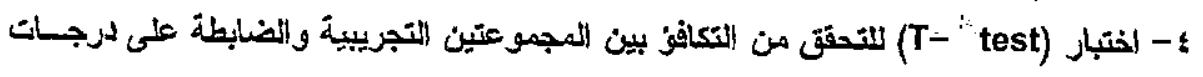

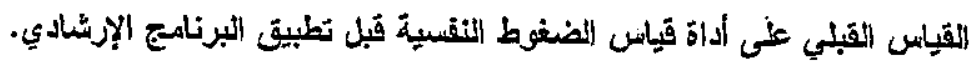


فعالية برنامج إرشئاد جمعي في خفض مستوى الضغط النفسي لدى أسر الأطفل المعاقين عقليا

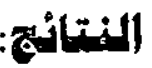

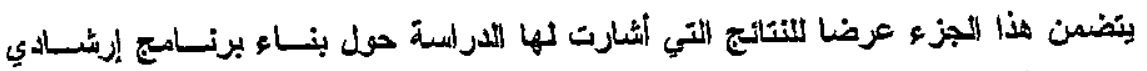

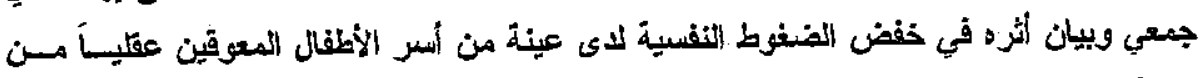
مدينة اريد/ المملكة الأردنية الهاثمية.

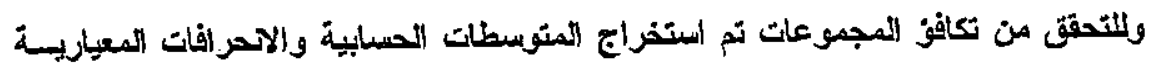

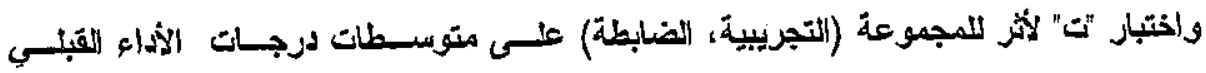

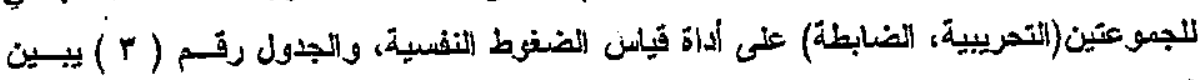
: sij

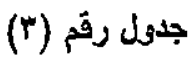

المتوسطات الحسابية والاتحر افات المبيارية واختبار "ت" لأثر المجموعة على درجات مفياس

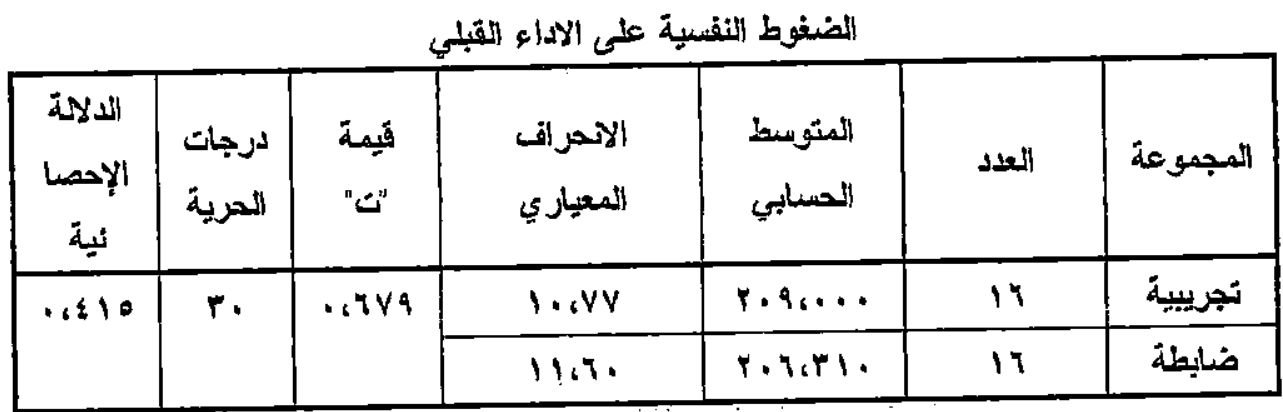

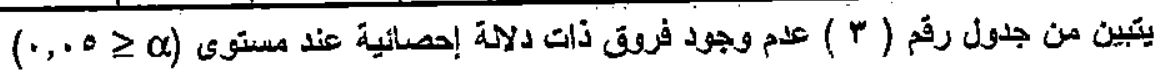

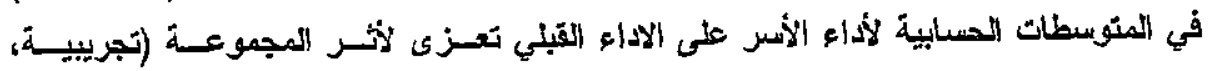

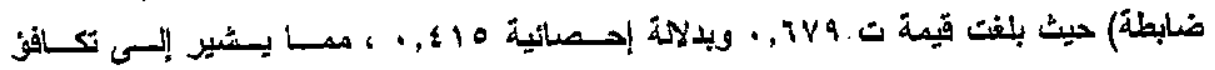
المجموعات.

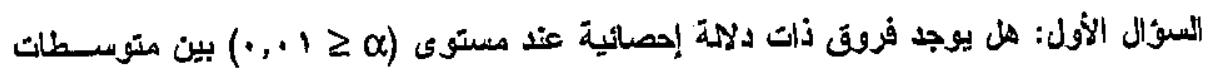

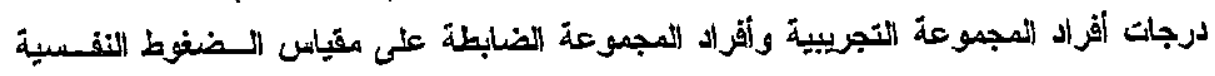
يعزى للبرنامج الإرشادي.

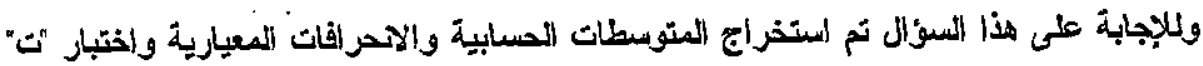

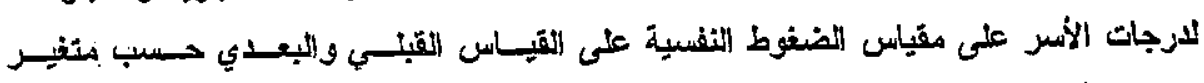

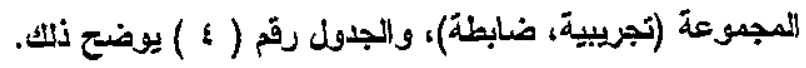


فعالية برنامتج إرشاد جمعي في خفض مستوى الضنط النفسي لدى أسر الأطفال المعاقين عقليا

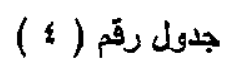

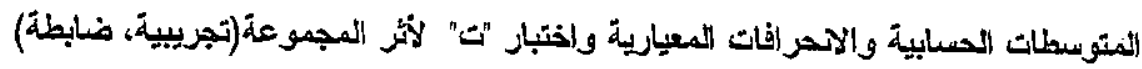
على متوسطات درجات الأسر على مقياس الضفوط النفسية (القيانس القبّلي والبعدي)

\begin{tabular}{|c|c|c|c|c|c|c|}
\hline الإحصائية & درجات & "تيمة & الالانحراف & الملمسابي & العلدد & البجموعة \\
\hline \multirow[t]{3}{*}{$\cdots$} & \multirow[t]{3}{*}{$r}$. & \multirow[t]{3}{*}{$11,9 v 5$} & A.91Y & 174.41 & 17 & تجريية \\
\hline & & & lotrt. & Y. VGIYO & 17 & ضابطة \\
\hline & & & & 114.818 & ry & مروع الكماكي \\
\hline
\end{tabular}

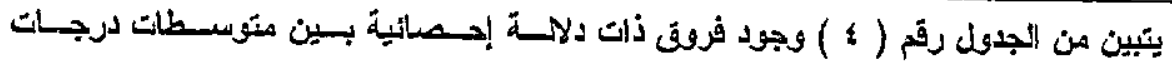

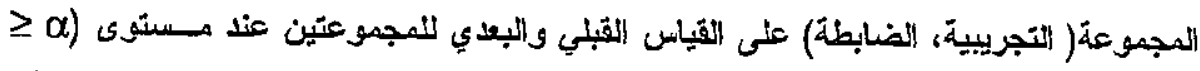

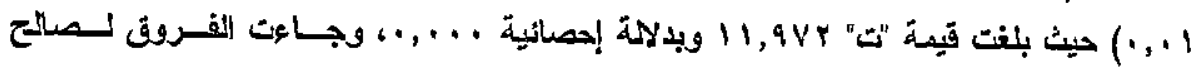

المجموعة التجريبية.

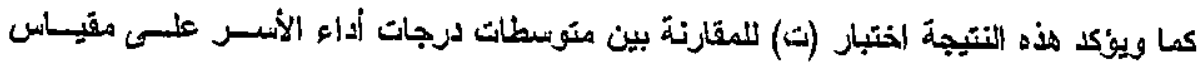

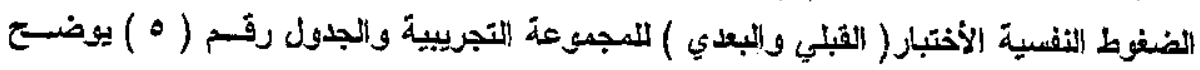

$$
\text { جلمل رقم (0) }
$$

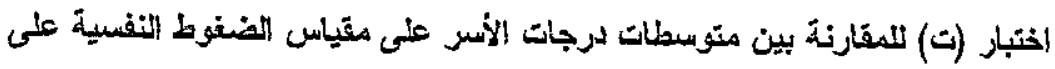

\begin{tabular}{|c|c|c|c|c|c|c|}
\hline الإحصائية & درجات & "قيمة & المعياري & الملتوسطيل & العدد & البجموعة \\
\hline \multirow[t]{2}{*}{$\cdots$} & \multirow[t]{2}{*}{10} & \multirow[t]{2}{*}{$1.0 \mathrm{OYY}$} & $1.6 \mathrm{VV}$ & $r \cdot q$ & 14 & قبلي \\
\hline & & & A.9) & 174 & 17 & بعلدي \\
\hline
\end{tabular}

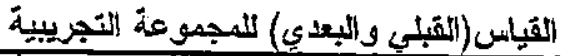

يتبين من الجدول رقم ( • ) وجود فروق ذات دلالمة إحصائية بين متوسطات درجيسات

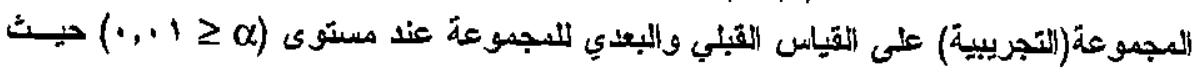

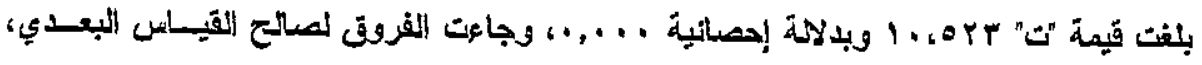

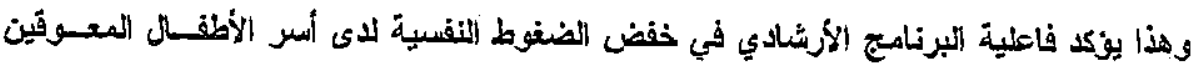


فعالية برنامج إرشاد جمعي في خفض مبتوى الضنط النفسي لدى أسر الأطفلل المعاتين عتليا كما ويؤكل فاعلية البرنامج الأرشادي في خفض الضفوط النفسية لاى أسسر الأطفـال

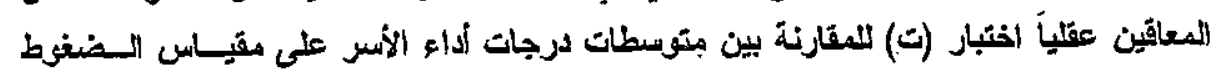

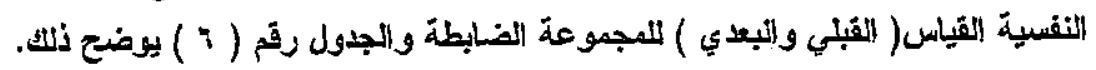

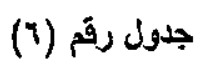

اختبار (ت) للمقارنة بين متوسطات درجات أداء الأسر على مقياس الفنفوط النفسية على

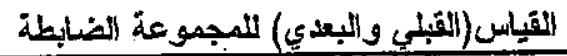

\begin{tabular}{|c|c|c|c|c|c|c|}
\hline الإحصائية & لالحرية & "تيمة" & الاتحريازي & المسنوسبط & العلد & المجموعة \\
\hline \multirow[t]{2}{*}{$.00 . v$} & \multirow[t]{2}{*}{10} & \multirow[t]{2}{*}{. ‘ } & 11.7. & Y. Y,YIY & 11 & قبلي \\
\hline & & & 1.,Yr & $Y_{1} V_{6} \mid r_{0}$ & 18 & بعدي \\
\hline
\end{tabular}

يتبين من الجدول رقم ( آ ) علم وجود فروف ذات دلالة إحصائية بين متوبسطات درجسات

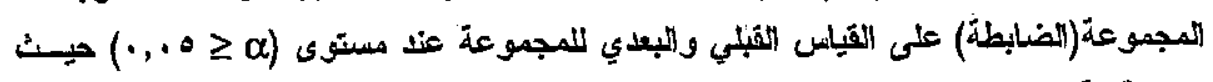

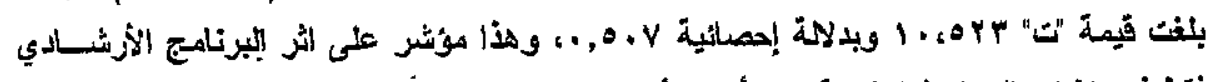
فقط في خفض الضغوط النفسية لاى أسر الأطفال المعوقين عقلياً.

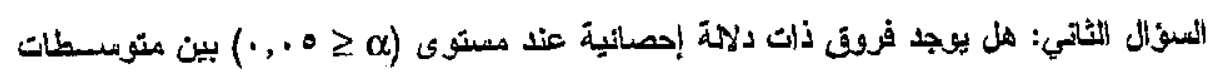

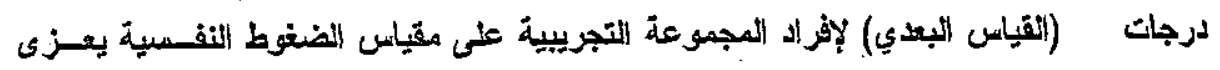
لمتفير الجنس.

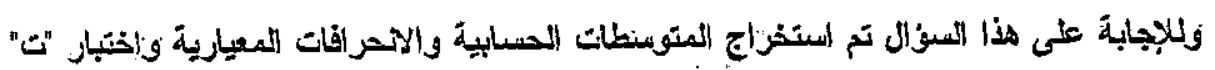

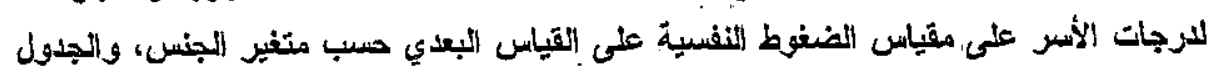
رقم ( V) يوضع نلت.

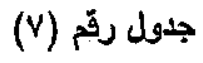

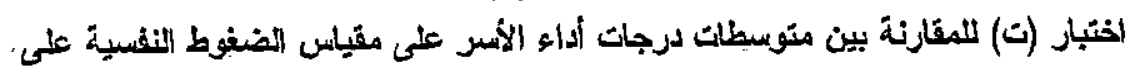

\begin{tabular}{|c|c|c|c|c|c|c|}
\hline الإلدلالة & دربحات & "قيمة & الانحراف المعياري & الملمسابي & العدد & متغير الجنس \\
\hline \multirow[t]{2}{*}{ r } & \multirow[t]{2}{*}{$1 \varepsilon$} & \multirow[t]{2}{*}{.0911} & $9,9 \leq r$ & irnco. & 1 & ذكور \\
\hline & & & VovVr & $17 \varepsilon, 18$ & $\wedge$ & إناث \\
\hline
\end{tabular}


فعاتية برنامج إرشند جمحي في خفض مسنتوى الضغط النفسي لدى أسر الأطفال المعاقين عقليا

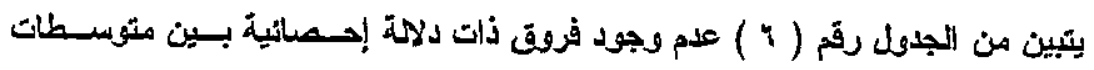

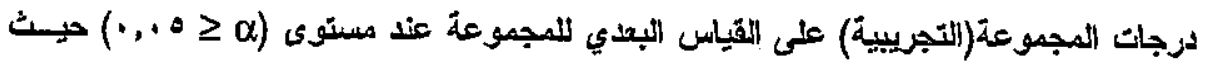

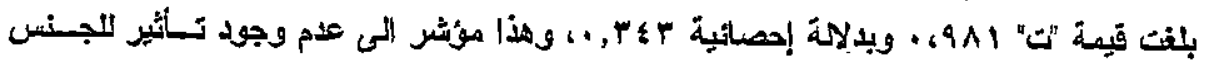

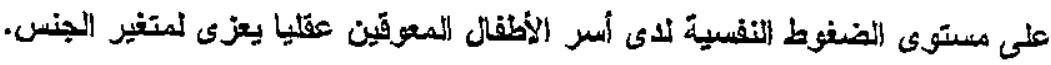

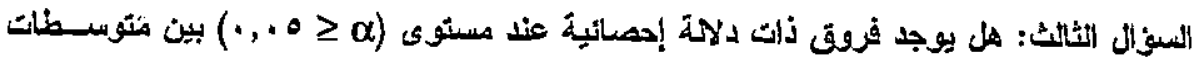

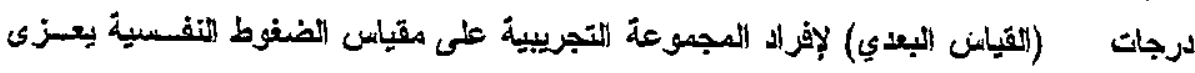

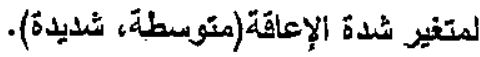

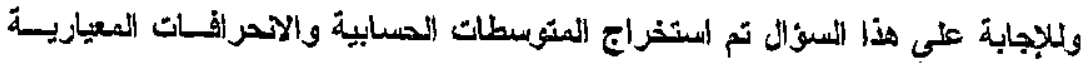

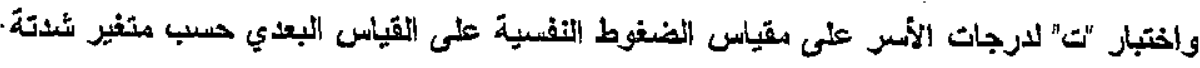

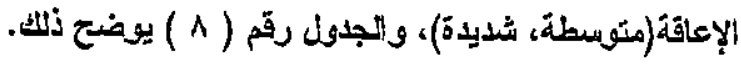

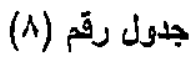

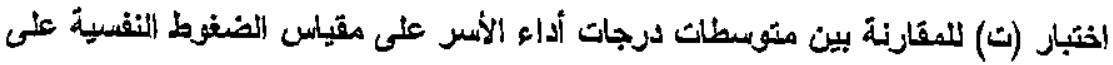

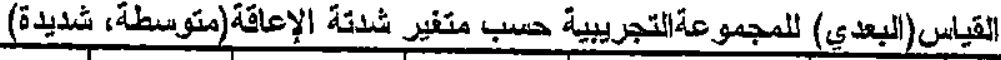

\begin{tabular}{|c|c|c|c|c|c|c|}
\hline الإلالائة & درجات & "تيهة & الالمعرانياري & الحسابي & اللعلد & الإعافَة \\
\hline \multirow[t]{2}{*}{$\ldots .1 \leq$} & \multirow[t]{2}{*}{18} & \multirow[t]{2}{*}{$r_{4} A_{10}$} & $3 . .0$ & $171.11 \mathrm{ro}$ & $\wedge$ & متوبسطة \\
\hline & & & $\Lambda_{6} \leqslant \Lambda^{\circ}$ & ivi.e... & $\wedge$ & شنديدة: \\
\hline
\end{tabular}

يتبين من الجلول رقم ( 1 ) وجود فروق ذات دلالمة إحصائية بين متوسطات درجيات

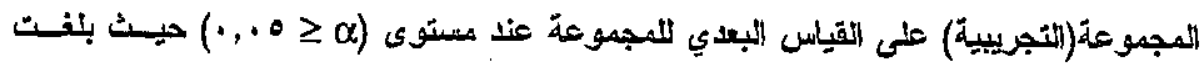

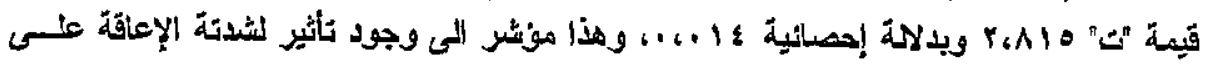

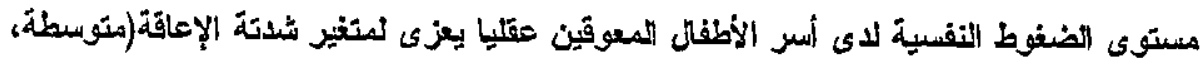

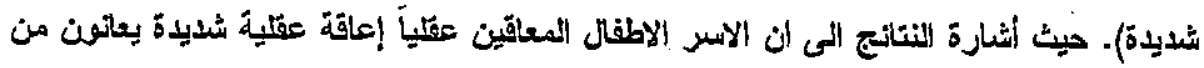

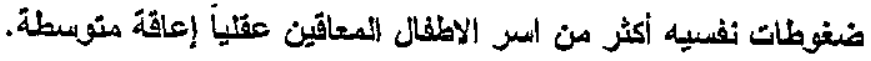

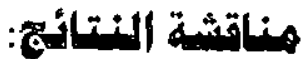

هافت الدراسة الحالية المى التعرف على مستوى الضفوط النفسية لأى اسر الاطفسال المعساقين

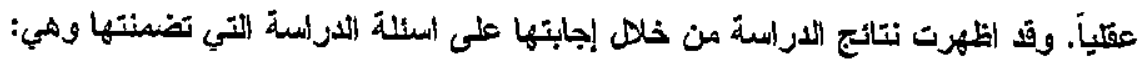
الكسؤال الأول: 
فعالية برنامج إرشاد جمعي في خفض مستوى الضغط النفسي لدى أسر الأطفلل المعاقين عمثيك

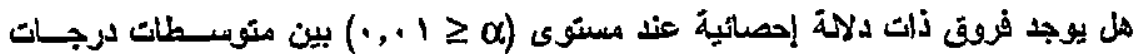

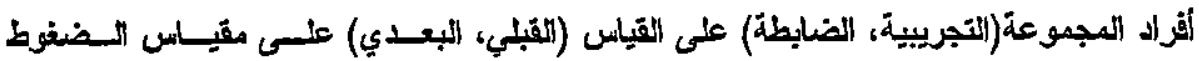

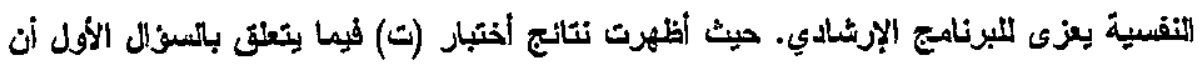

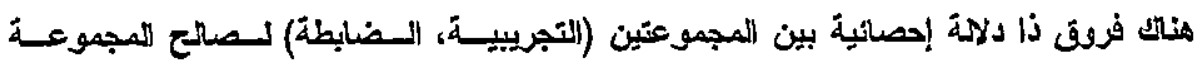

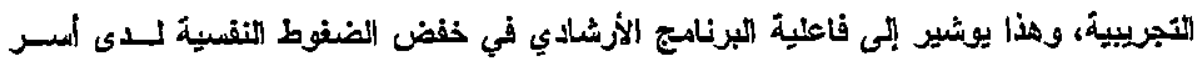

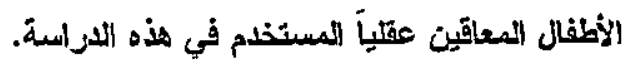

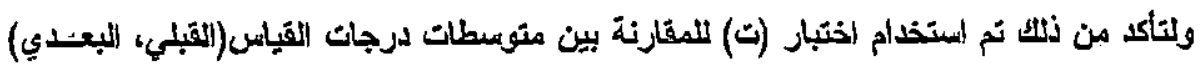

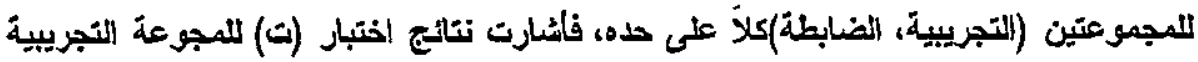

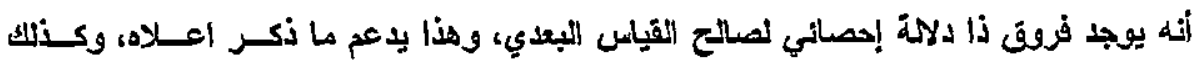

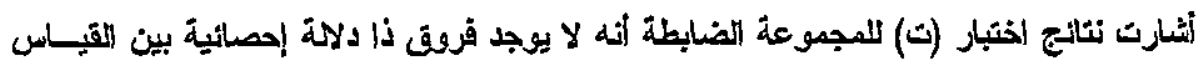

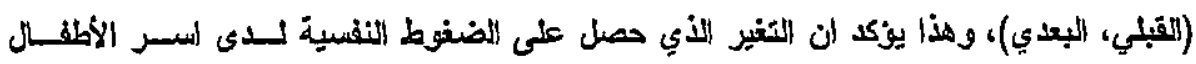

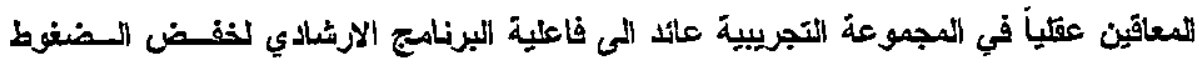

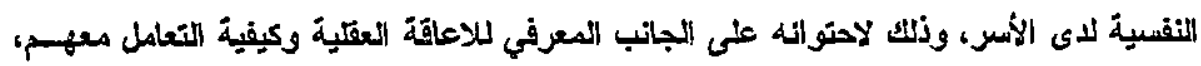

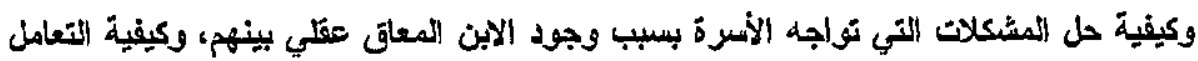

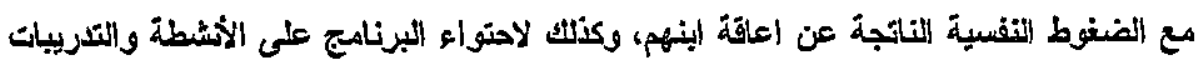

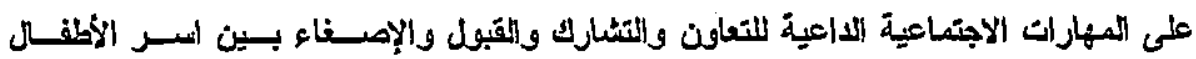
المعاقين عقياً.

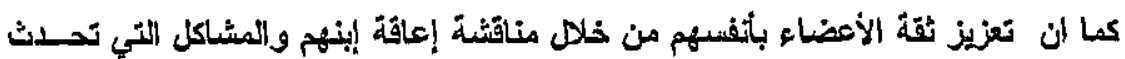

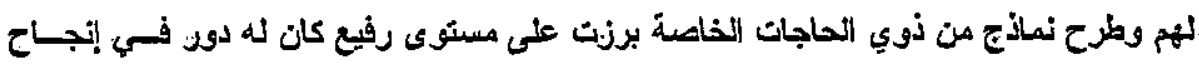
إلبرنامج الإرشادي.

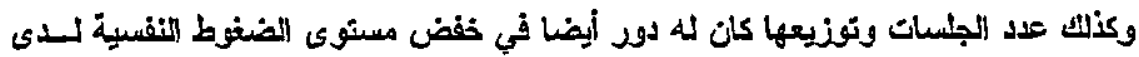

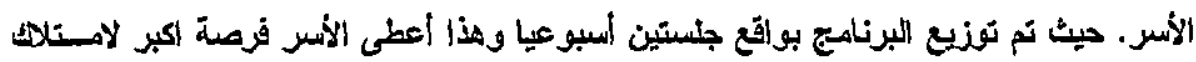

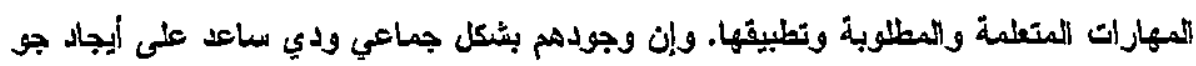

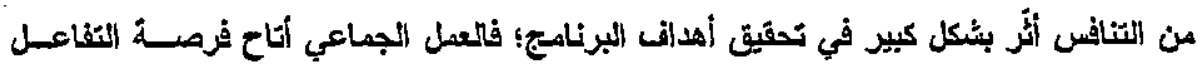

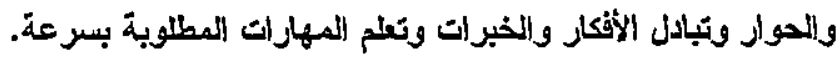
السؤال الثانتي:

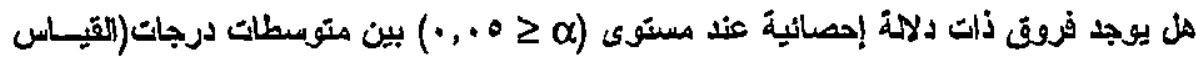

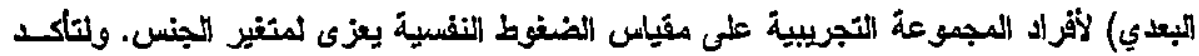

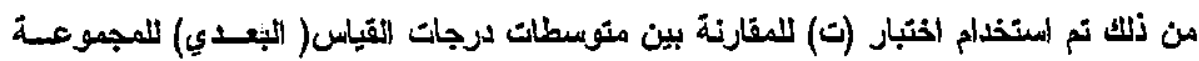

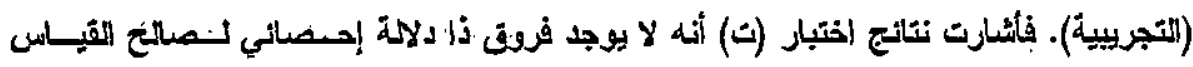


فعالية برنامج إرشاد جمعي في خفض مستوى الضفط النفسي لاى أسر الأطفل المعاقّين عثليا

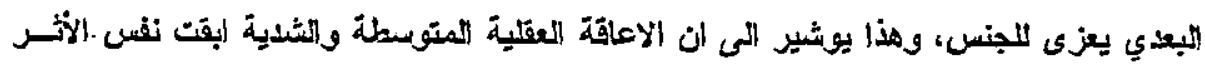

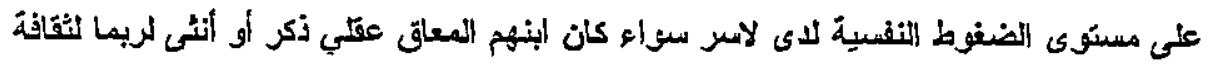

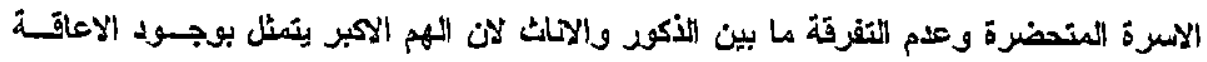

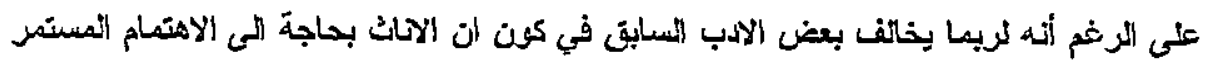

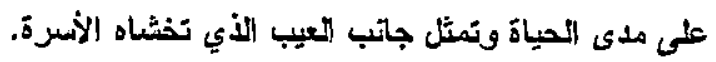
السؤال الثالتث:

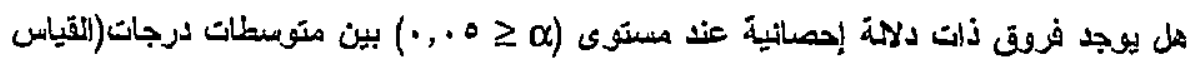

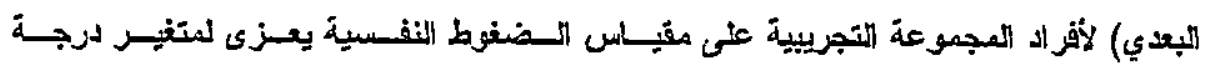

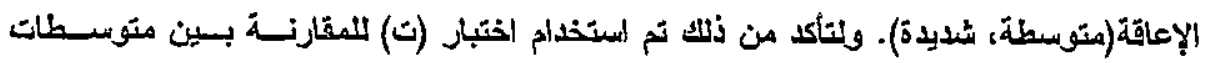

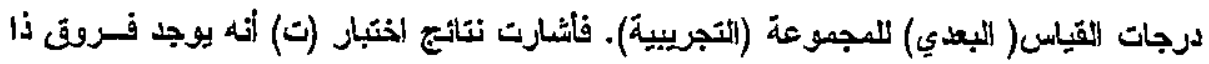

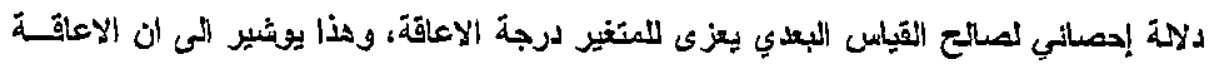

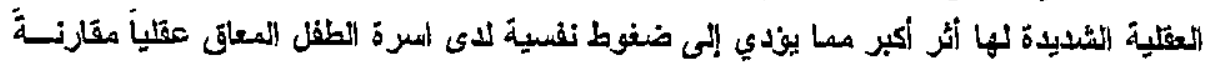

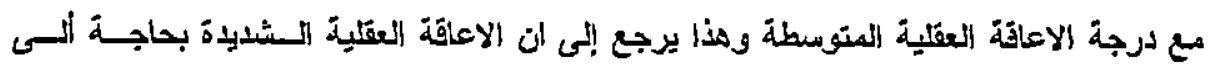

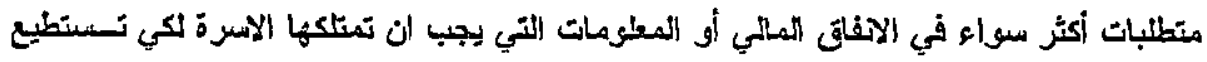

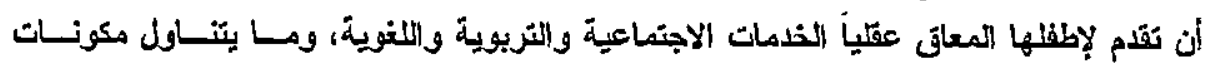

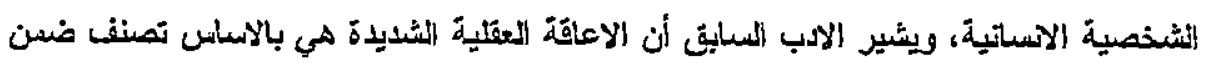

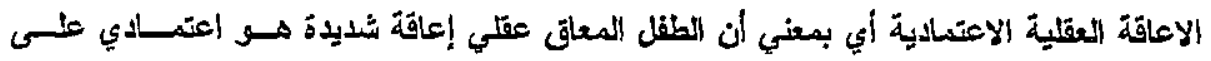

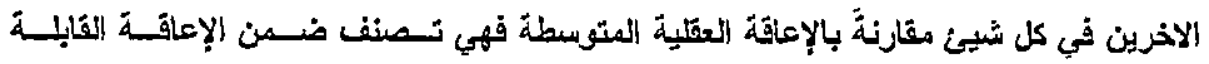

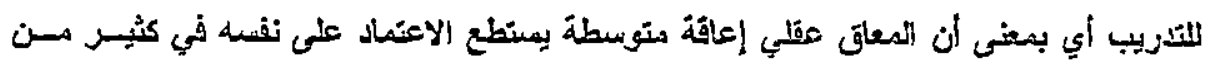

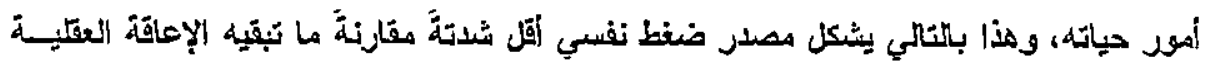

$$
\text { الاشعديدة على الأسرة }
$$

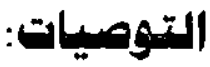

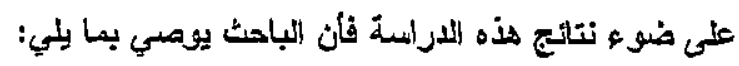

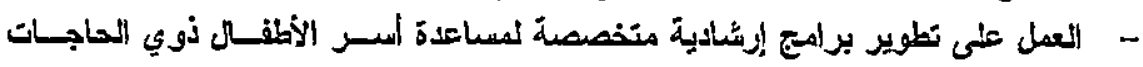

الخاصة في كيفية التعامل مي الضنوط التفسية التي تعاني منها، وإسلآيب خفضها.

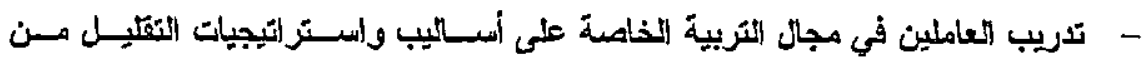
الضنوط النفسية النتي تعاتي منها الأسر.

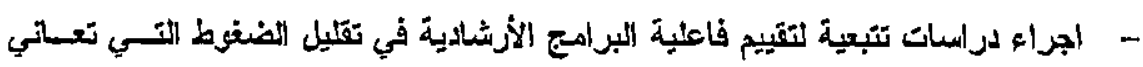
منها أسر ذوي الاحتياجات الخذاصة. 
فُعالية برنامج إرشاد جمعي في خفض مشتوى الضنط النفسي 'لدى أسر الأطفال المعاقين عفليا

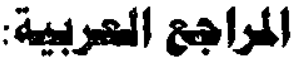

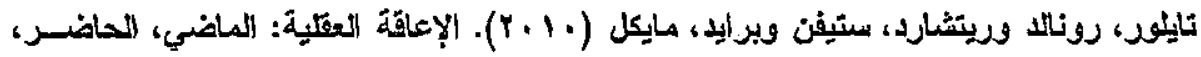
إلمستقبل، ترجمة دصطفى محد، عمان، دار الفكر.

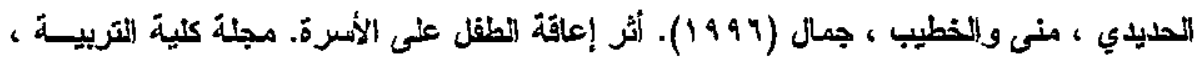

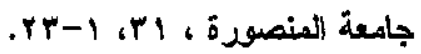

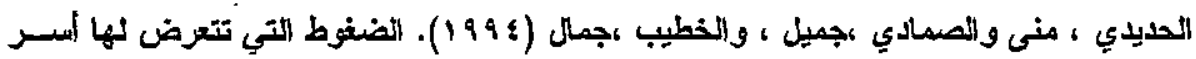

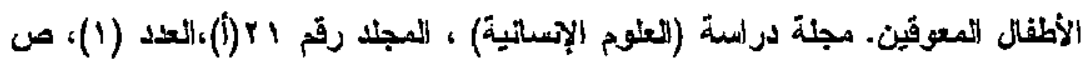
$.4 \div-\gamma$

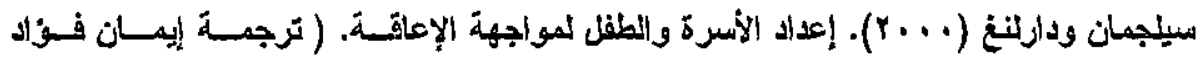

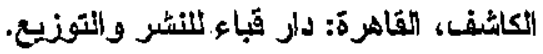

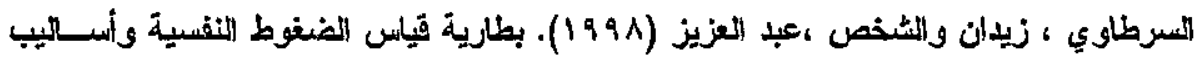

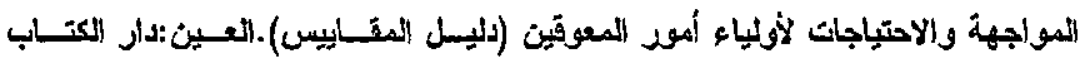
الجامعي.

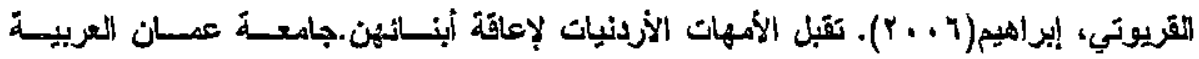
الثاراستات المليا:عمان، الأردن

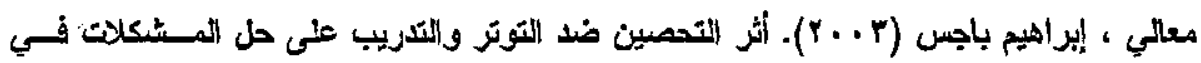

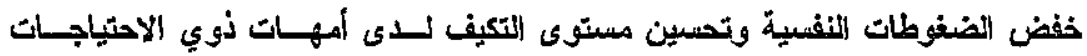

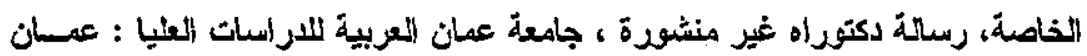
، الأردن.

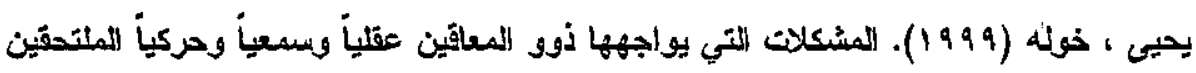

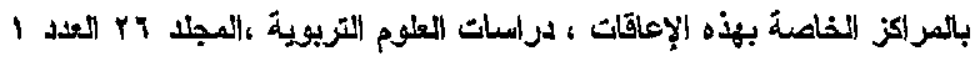

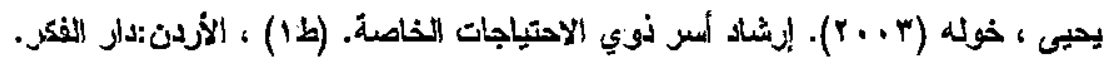
المراجي الانبليربية:

Abboud, S. (2003) Stress, social support and well-being of Arab mothers of children with intellectual disability who are served by welfare services in northern Israel.. Journal of Intellectual Disability Research, V47, pp264-272.

Blatcher, J. and Mclntyre, L. (2006) Syndrome Specificity and Behavioral Disorders in Young adults with Intellectual 
فعالية برنامج إرشاد جمعي في خفض مستوى الضغط النقسي لاى أسر الأطفال المعاقين عقليا

Disability: Cultural Differences in Family Impact. Journal of

Intellectual Disability Research, Vol 50, part 3, pp 184-198.

Brandon, D, Peter. \& Hogan, Dennis. (2001). The Effects of children with disabilities on mothers' exit from welfare. paper prepared for the september 20-21, 2001, Research Institute "The Hardto-Employ And Welfare Reform".

Brawn, S.D.(1980). Coping skills training: an evaluation of a psychology educational program community mental health setting: Journal of Counseling Psychology, 27, 4, 340-345.

Calderson, Rose, $M$ and Greenberg, M, T. (1999) Stress and Coping.in

Hearing Mothers of Children with Hearing Loss: Factors

Affecting Mothers and Child Adjustment. American Journal of the Deaf, v.144, N.1, PP. 7-18.

Carpenter.(2000). Meeting the Needs of Families of Children with Disabilities. British Journal of special Educations, 27, 135-144.

Craig, J., and Swan, S. (2000, May1) Effect of Disability on Parental Stress. The Lancaster County Center for Autism. Article Retrieved September 27,2003, from.

Clayton, E . and ladd, Tucker, (2000) Psychologist Self-Help. Mental Health Net.

Darling, R. B., \& Baxter, C. (1996). Families in Focus: Sociological methods in early intervention. Austin, TX: Pro-Ed.

Ellman, N. S. (1991). Family therapy In M.Seligman (Ed.). The family with handicapped ( $2^{\text {nd }}$ ed, pp.369-406) Boston : Allyn \& Bacon.

Turner ,A.L. (1980). Therapy with families of Mentally retarded child. Journal of Marital and Family Therapy 6 - 167-170

Gammon, E. \& Rose, S.D.(1991). The Coping skills training program for parents of children with developmental disabilities: An Experimental Evaluation. Research on Social work practice, Vol.,1, Issue 4,pp. 244-257.

Italinna M, \& Saloviita, T. \& E. Leinonen (2003). Explaining the parental stress of fathers and mothers caring for a child with intellectual disability: a Double ABCX Model, Journal of Intellectual Disability Research.V 47,pp 300-312 .

Marsh. D.T.(1992). Families and Mental Retardation one Madison Avenue. New York.

Mcdonald, T \& Gregoire, K, (1997). Building a model of family caregiving for children with emotional disorders. Journal of Emotional Behavioral Disorders,Vol.5. Issue 3, pp. 138-149.

Meichenbaum, D, (1996). Stress inoculation training for coping with stresses, The Clinical Psychologist. 49, 4-7. 
فعلية برنامج إرشُاد جمعي في خفض منتوى الضنفط النفسي لدى أسر الأطفال المعاقيّن عمثيا

Rolland, J. S.(1993). Mestering family challenges in series illness \& disability. In F. Walsh (ed.), Normal Family processes $\left(2^{\text {nd }}\right.$ ed., pp. 444-473). New York: Guilford Press.

Payane and Stone man. L. (1997) Fathers and Mothers Perceptions of Father Involvement in Families with Young Children with Disabilities. Journal of Intellectual \& Developmenal Disability Vol. 26,_Issue 4, PP. 324-339.

Shin, Jin $Y$ (2003). Well-being of mothers of children with mental retardaticra: in evaluation of the Double $A B C X$ model in a crossculkeral context. Asian Journal of Social Psychology,V 6,pp171184.

Singer ,G .H . S., Irvin ,I . K., and Hawkinges, N., (1988). Stress management training for parents of children, with severe Handicaps, Journal of mental retardation,26,269-277.

Singhi,G., Pershad, D.Singhi, S and Walia, B. (1990). Psychological Problems in Families of Disabled Children. June ,63(pt2): PP.173182.

Smith, J. (2003). when it is my turn? Sibshop: Aspecial Time For Siblings. SESA, WWW.disabilitysolutins.org. 
فعلية برنامج إرشاد جمعي في خفض مستوى الضغنط النفسي لاى أسر الأطفال المعاقين عقليا

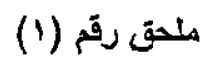

مقياس الضضوط النقسية

الأسبرة الفاضلة السلام عليكم sرحمة الله ويركاته ويعد:-

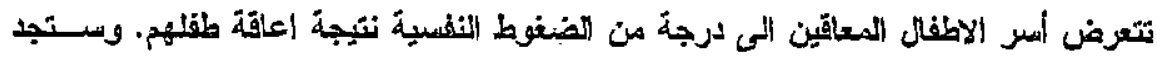

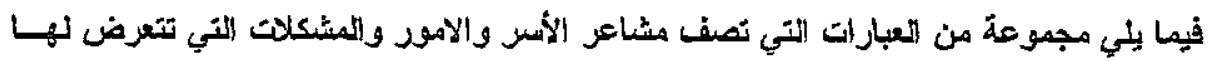

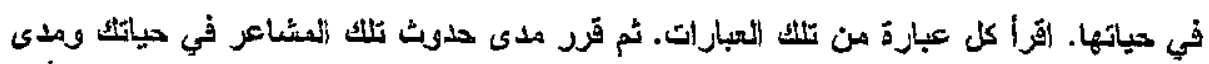

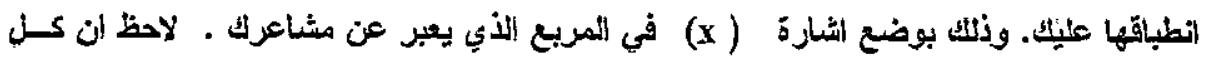

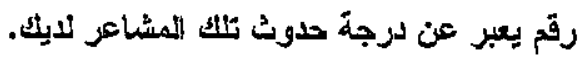

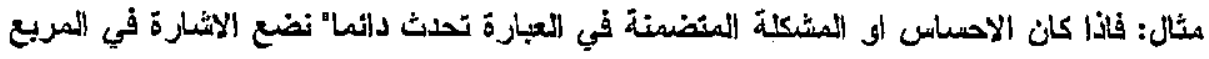
الاول هيكا

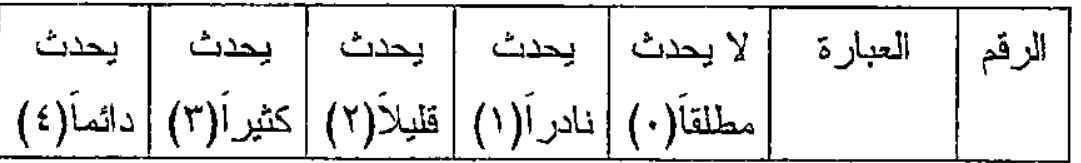

فاذا كاتت المشاعر والمشكلات المتضمنة في العبارة لا تحدث مطلقا ضع الاثشارة فسي المريسع ألاول.

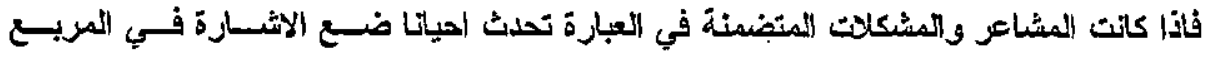
الأني، وهكنا.

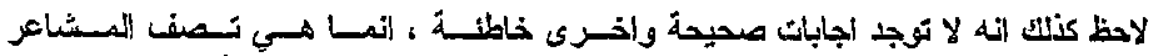

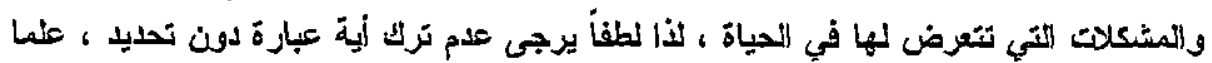

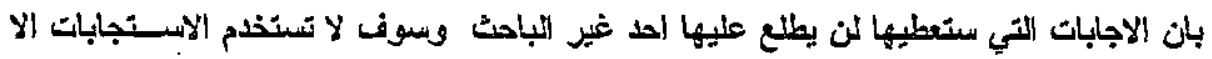

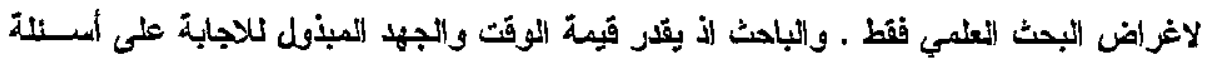

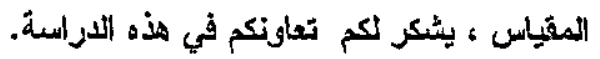


فعلية برنامج إرشّاد جعي في خفض مستوى الضغط النفسي لاى أسر الأطفل المعاقين عقليا

\begin{tabular}{|c|c|c|c|c|c|c|}
\hline يحاثي & كيديراً & يحلئ & نيادث & لا بيطد & الفقرة & قو \\
\hline & & & & & أشعر باتخمول والكسل وعدم الرغبة في النشاط & 1 \\
\hline & & & & & أنسعربالتعب و الارهاتي عقب أبي نشاط وليو بسنيط. & $r$ \\
\hline & & & & & أعاني من الاليق وصعزبية النوم & $r$ \\
\hline & & & & & أمزن وأبكي لابسط الأسبِاب & $\varepsilon$ \\
\hline & & & & & لا أشعز باي متعة في حياتي & $\therefore$ \\
\hline & & & & & أنشعر بضيق في المنفس دون سبب واضنح & 1 \\
\hline & & & & & واضتعرض لاضطر ابنات في دقات القلب دون سـبب & $v$ \\
\hline & & & & & أعاني من الصعداع دون سبب واضح & $\Lambda$ \\
\hline & & & . & & الأسبابي أستطيع التحكم في أعصابي وأتـهم لأبسسط & 9 \\
\hline & & & & & اللوم نفسي بثُدة علي أبسط الأثبياء & 1. \\
\hline & & & & & يصعب علي اتخاذ أي قرار ولئ بسيط & 11 \\
\hline & & & & & أنسعر بفقك الشيهية و علم الرغبة في تناول الطعام & Ir \\
\hline & & & & & أثتعر بالضيق والاختئق في وجود الإخرين & ir \\
\hline & . & & : & & 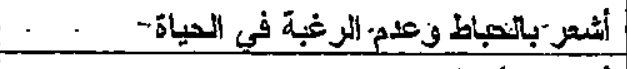 & $1 \xi$ \\
\hline & & & & & أتُّعر بالأم في مغاصلي دين سبب واضبح & 10 \\
\hline & & & & & يصعب علي تذكر الأشنياء ولئ النبسيطة & 14 \\
\hline & & & & & أعاتي هن إضطر إبات الهضمـ & iv \\
\hline & & & & & 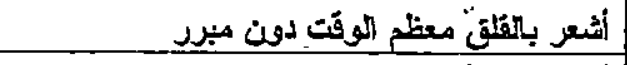 & 11 \\
\hline & & & & & أبتذوقي النطعام ألم مستمر بمعدتي يفقلني الاسنستّاع & 19 \\
\hline & & & & & 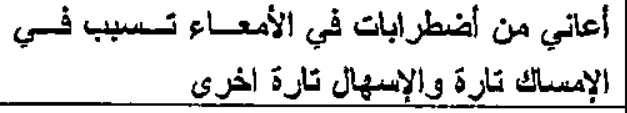 & $r_{0}$ \\
\hline & & & & & أنشعر أن أسرتي مهلدة بالاتهيار بسسبب ابنسي & ri \\
\hline & & & & & 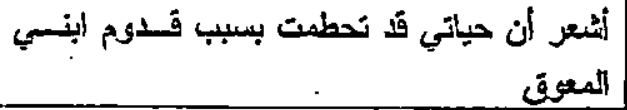 & $r r$ \\
\hline
\end{tabular}


فمعامة برنامج إرشاد جمعي في خفض مستوى الضغط النفسي لدى أسر الأطفال المعاقين عتليا

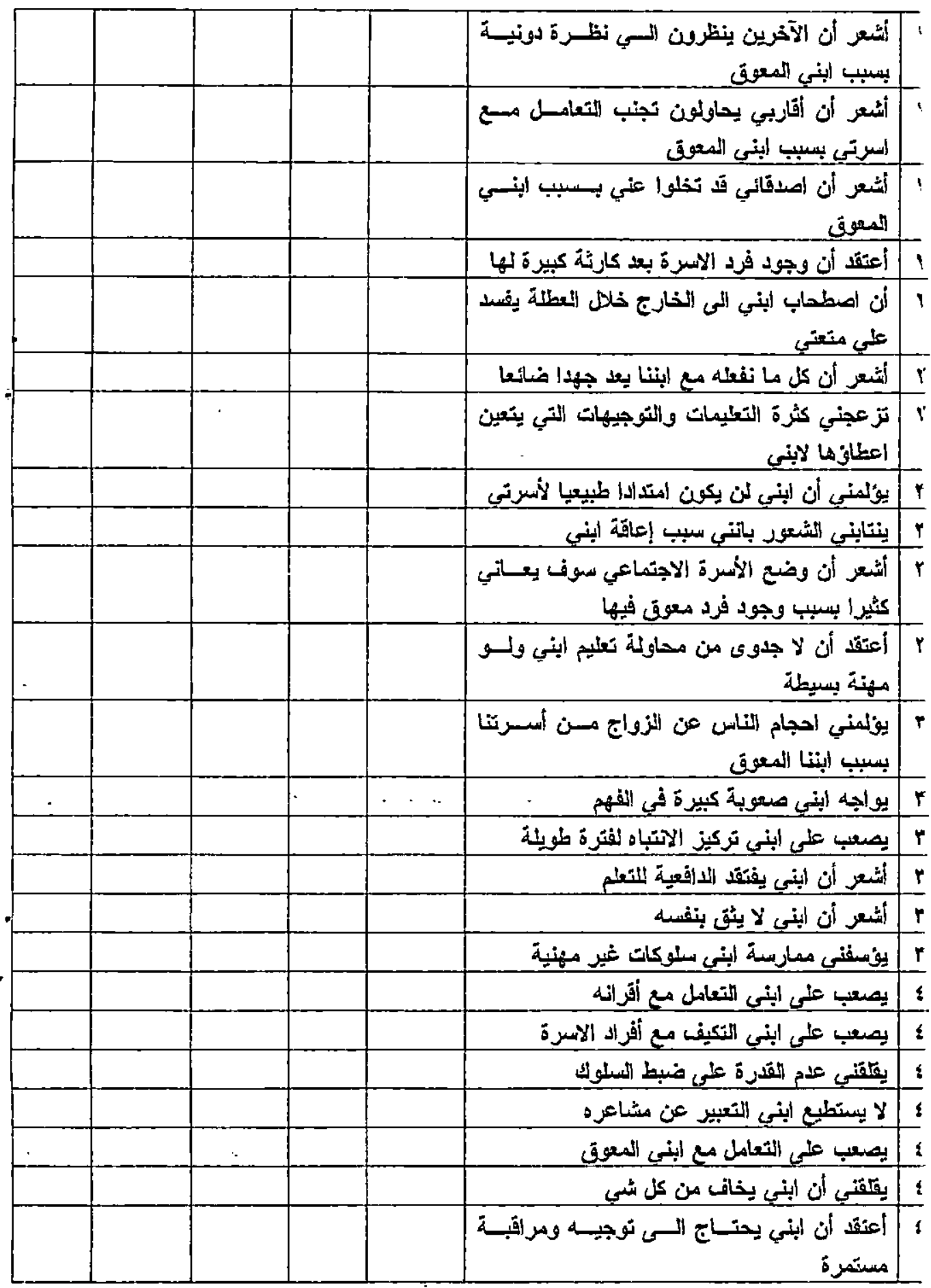


فعالية برنامجز إرشاد جمعي في خفض مستوى الضنط النفسي لاى أسر الأطقال المعاقين عقليا

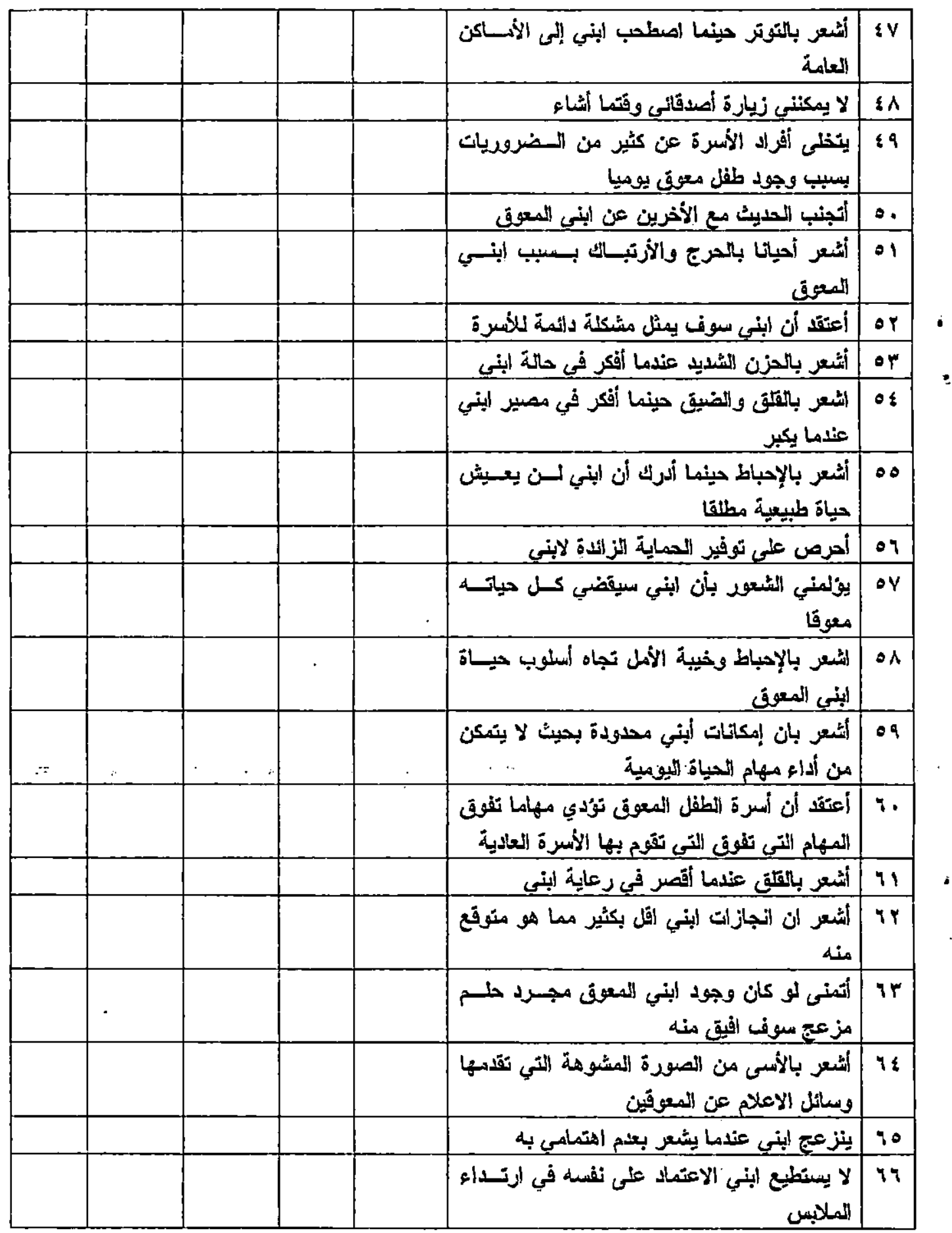




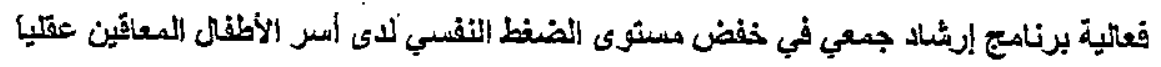

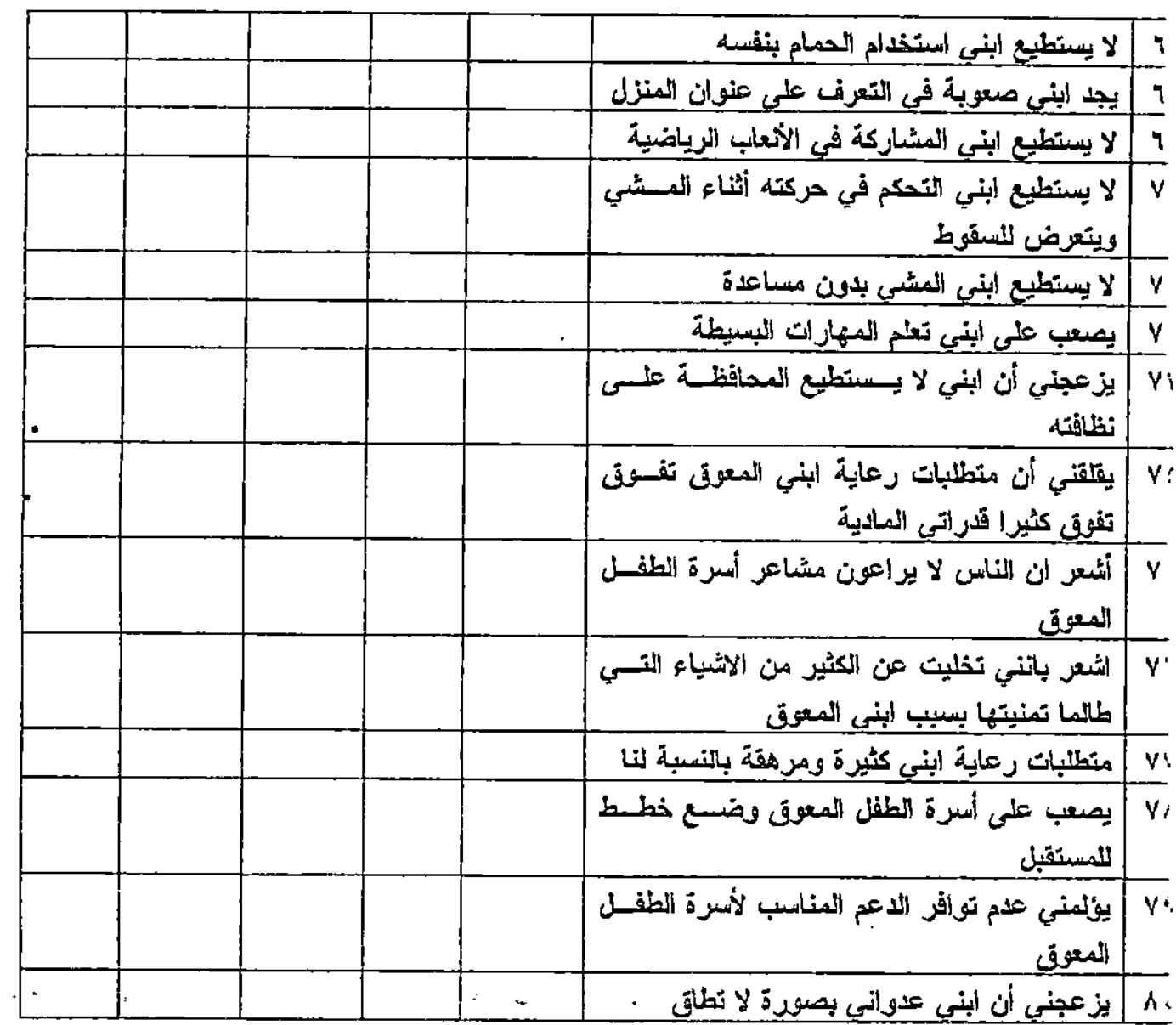

